\title{
Kazanie Skargi Jana Matejki w kontekście ówczesnej wiedzy o epoce i poglądów na dzieje Polski
}

Kazanie Skargi należy do najbardziej znanych dzieł Jana Matejki, zaliczano je też nieraz do najwybitniejszych. Wskazywano na jego wyjątkowe miejsce tak w twórczości artysty, jak i w dziejach polskiego malarstwa w ogóle. Lucjan Siemieński, ówczesny autorytet w sprawach sztuki, ogłosił tuż po jego wystawieniu, że historia Polski „ma już swego malarza" ${ }^{1}$, co ogólnie przyjęto z aprobatą. Po latach Stanisław Tarnowski stwierdził zaś z emfazą, że wraz ze Skargą narodziło się polskie malarstwo². Ten autor cennej biografii Matejki, zasadniczo krytyczny wobec jego „fałszywej", wykraczającej poza możliwości malarstwa, skłonności do wyrażania rozbudowanych "historiozoficznych myśli"3, Kazanie Skargi uznał za zasadniczo wolne od tej przypadłości i podkreślał, że „obraz tłumaczy się sam, od razu, bez objaśnień i komentarzy"4. Podobnie uważał Stanisław Witkiewicz, w niemniejszym stopniu wrogi idei przedstawiania na płótnie rozpraw historycznych czy historiozoficznych ${ }^{5}$. Te konstatacje należałoby jednak poddać konfrontacji z sytuacją

1. L. Siemieński, Wystawa obrazów w Krakowie, "Czas" 1864 nr 36 (z 14 maja), s. 1.

2. Zob. S. Tarnowski, Matejko, Kraków 1898, s. 72-73.

3. S. Tarnowski, [recenzja Unii Lubelskiej] Kronika literacka, „Przegląd Polski" 4 (październik 1869) z. 2, s. 120.

4. S. Tarnowski, Matejko, dz. cyt., s. 78; niemal identyczna konstatacja na s. 76 .

5. Witkiewicz pisał: „można nie znać historii polskiej, można nie wiedzieć nic o stosunku ludzi, którzy ten obraz wypełniają, a jego treść najistotniejsza, najgłębsza, to jest niezmienna treść ludzkiej duszy, będzie zawsze dla każdego jasna, ponieważ wyrażają ją z niesłychaną siłą i ścisłością wyrazy uczuć, skrystalizowane na twarzach" (Matejko, Lwów 1912, s. 226). 
widza obcego, a podstawą mogą być reakcje francuskie na ekspozycję dzieła na Salonie w Paryżu w 1865 roku. Jego temat uznano tam zgodnie za niejasny ${ }^{6}$, co zresztą nie przeszkodziło artyście odnieść sukcesu.

Pokazuje to w sposób oczywisty, że jeśli dzieło to jest zrozumiałe, to jedynie pod warunkiem pewnej znajomości właściwej problematyki historycznej. I przecież elementy takiej wiedzy są dobrze widoczne w rozlicznych refleksjach na jego temat. Zarazem ma ona z reguły charakter nader ogólny, a dotyczy osoby słynnego jezuity, treści jego przestróg oraz różnie ocenianych i stanowiących przedmiot zasadniczych sporów czynników destrukcji Rzeczypospolitej. Jeśli przypominam rzecz tak oczywistą, to po to, by zadać retoryczne pytanie: czy można orzec, w jakim stopniu artyście wolno oprzeć malarską narrację na szczegółowej wiedzy historycznej oraz oczekiwać jej od widza, by mógł on w pełni partycypować w recepcji dzieła, jakiej zaś granicy nie może przekraczać? I czy należy ubolewać, że musi on dawać wskazówki werbalne, aby umożliwić adekwatną recepcję (nawet jeśli są to tylko nazwiska ukazanych postaci) oraz odpowiadać odmową udziału w sugerowanej w ten sposób formie lektury dzieła? Praktyka sprowadzania historycznej materii obrazów do ogólników jest - czy to podejmowanym z premedytacją, czy bezwiednym - ignorowaniem intencji Matejki, który deklarował przecież, że dąży do ukazania całej epoki i przywoływał w tym celu konkretne wydarzenia i procesy, przedstawiając na płótnie reprezentatywne dla nich postacie.

Nie uważam, by siła malarstwa Matejki polegała na jego inwencji w kreowaniu przy pomocy pędzla złożonej problematyki poszczególnych epok dziejów narodu. Leży ona istotnie przede wszystkim w zdolności do nawiązania relacji z widzem na poziomie patriotycznych emocji, co osiągał zwłaszcza, kreując tak przekonująco tę opisywaną przez Witkiewicza "rasę" twórców polskiej historii - bohaterów o potężnych osobowościach, których dusze obrazują w jego dziełach „z niesłychaną siłą i ścisłością wyrazy uczuć, skrystalizowane na twarzach"7. Ale też sądzę, że programowe abstrahowanie od bogactwa materii historycznej dzieł Matejki bądź ograniczanie się do luźnych, niesystematycznych spostrzeżeń w tym zakresie znacząco jego twórczość zubaża. Ponadto twierdzę, że niemal cała dotychczasowa literatura

6. Por. M. Zgórniak, Matejko w Paryżu, Kraków 1998, s. 117, s. 122-127.

7. $\quad$ Por. wyżej przypis 5. 
przedmiotu traktowała ją w ten sposób i nie inaczej jest również w przypadku Kazania Skargi ${ }^{8}$.

O kompozycji tej pisano wiele; ogół traktujących o niej prac przywołał ostatnio Kazimierz S. Ożóg w pracy na temat ikonografii Skargi ${ }^{9}$. Wśród autorów ostatnich kilkudziesięciu lat, którzy poświęcili obrazowi Matejki odrębne teksty, nie brakuje uznanych uczonych, ale długo nie podejmowano próby względnie kompletnego odczytania zawartej tam wizji epoki rokoszu sandomierskiego i dymitriad. Mieczysław Porębski pisał w pracy z lat 50. XX wieku, że twórczym założeniem malarza było „pokazać epokę, jej mechanikę, spięcia, postawy, interesy - a nie kronikarski epizod". Zarazem autor niczego takiego konkretnie nie wskazał, dostrzegł jedynie, zgodnie z duchem czasu, aspekt klasowy dzieła. Pisał, że „głos sprawiedliwości nie przełamie tego solidarnego frontu [słuchających kazania elit], że wszyscy jak tu są pójdą do kresu swych historycznych przeznaczeń, pociągając za sobą owo dobro publiczne, którego mienili się stróżami"10. Warto tu zauważyć, że autor mógł się o tym dowiedzieć z prac historyków, a nie z treści obrazu. Wybitny znawca XVI i XVII wieku, Janusz Tazbir, zajął się zaś dokonaniami pierwowzorów historycznych postaci Kazania Skargi, stwierdzając niezgodność ukazanej tam sceny z prawdą dziejową. Nie zauważył jednak, że dzieło odnosi się do kilku zasadniczych problemów tego okresu dziejowego, a jego przesłanie sprowadził do „wizji warstwy rządzącej, która pozostając głucha na wezwanie do radykalnych reform szykuje państwu zagładę"11. Dwa interesujące eseje,

8. Warto jeszcze zauważyć, że krytycy nie zawsze byli na tyle konsekwentni, by zachować wstrzemięźliwość wobec treści dzieła i roli postaci; Tarnowski nie wahał się twierdzić stanowczo, które kazanie wygłasza Skarga (Matejko, dz. cyt., s. 8182), potrafił odgadnąć, co w tym czasie myśli Zamoyski, wie też, jak swe czyny i zaniechania usprawiedliwia wobec sumienia Zygmunt III (Matejko, dz. cyt., s. 78-79).

9. $\quad$ K. S. Ożóg, Orzeł biały na tle mroków nocy. Ikonografia Piotra Skargi, Kraków 2012. Autor ograniczył się do zacytowania licznych refleksji na temat dzieła Matejki, nie przedstawiając własnego stanowiska.

10. M. Porębski, Jana Matejki "Kazanie Skargi”, Kraków 1953, s. 16-17, s. 22. Klasową interpretację tego obrazu autor powtórzył w późniejszej pracy, gdzie podkreślał ponadto, że „sukces Matejki był zwycięstwem historyka, który łączy w jedno klasową prawdę postaci" (Malowane dzieje, Warszawa 1962, s. 149-150).

11. Jako „warstwę rządzącą" artysta miał piętnować możnowładztwo, "głównego winowajcę rozbiorów", co autor uznał za niezgodne z poglądami jezuity, który obawiał się rządów "ograniczonej, samolubnej i anarchizującej szlachty" (J. Tazbir, "Kazanie Skargi" Jana Matejki, w: Sztuka i historia. Materiały Sesji Stowarzyszenia Historyków Sztuki, Kraków, listopad 1988, red. M. Bielska-Łach, Warszawa 1992, s. $50-51)$. 
odnoszące się do tego obrazu, napisała Maria Poprzęcka, nie przynoszą one jednak pogłębionego spojrzenia na jego treść, co zresztą nie było celem autorki - traktują one bowiem głównie o metodzie obrazowania i warsztacie malarskim Matejki ${ }^{12}$.

\section{Wezwanie narodu do pokuty A.D. 1864}

Próbę systematycznej i wnikliwej interpretacji Kazanie Skargi podjął dopiero ćwierć wieku temu Jarosław Krawczyk, sytuując obraz w kontekście szerokiej prezentacji ideowego oblicza artysty, w ramach analizy istoty przesłania historiozoficznego całej jego wizji dziejów Polski. Badając funkcję szeregu postaci i epizodów, autor doprecyzował głoszoną już w XIX wieku tezę, że intencją twórcy było napiętnowanie win przeszłości i wezwanie rodaków do pokuty ${ }^{13}$. Skarga Matejki to prorok par excellence, jego słowami historię narodu ocenia sam Bóg, i to On piętnuje rozplenione w Rzeczpospolitej zło, którego przykład (czy też swoistą kumulację) stanowi rokosz. Trudno się nie zgodzić, że Krawczyk uchwycił istotny motyw przesłania obrazu, ale trzeba też wskazać, że nie dostrzegł pewnych elementów znaczących, które moga wspierać jego argumentację, dopełniając przy tym istotnie zakres negatywnych zjawisk piętnowanych przez tytułowego bohatera. Zarazem pozostają wątpliwości, zwłaszcza w kwestii sensu owej pokuty: czy, jak zda się sądzić autor, oskarżenie przeszłości przez malarza jest równoznaczne z wezwaniem rodaków do rozpamiętywania win przeszłości i biernego oczekiwania na zmiłowanie niebios. I czy prócz tego należy zgodzić się z konstatacją, że do takiej pokutno-potępiającej wymowy da się sprowadzić wizję dziejów Polski w całej twórczości Matejki ${ }^{14}$.

12. M. Poprzęcka, Jak Jan Matejko malował "Kazanie Skargi”, w: Janowi Matejce w stulecie śmierci. Pamiętnik wystawy w Muzeum Narodowym w Krakowie, Kraków 1994; Co mówi Skarga, w: M. Poprzęcka, Kochankowie z masakrą w tle i inne eseje o malarstwie historycznym, Warszawa 2004.

13. Zob. J. Krawczyk, Matejko i historia, Warszawa 1990, s. 118.

14. Krawczyk usiłuje sprowadzić jego twórczość (a także uznawane za bliskie jej ideowo pisarstwo historyczne Szujskiego) do "ekspiacyjnych formuł" oraz "smutnego, ekspiacyjnego mesjanizmu biernej wiary" (Matejko i historia, dz. cyt., s. 158, 214). Z ujęciem tym polemizowałem w: H. Słoczyński, Smutek pokutników. O poglądach historycznych Matejki i Szujskiego, "Historyka. Studia Metodologiczne” 22 (1992), s. $91-101$. 


\section{Sposoby budowania narracji malarza-historiozofa}

Nie ma potrzeby dowodzić, że artysta dążył do zawarcia w swej twórczości przesłania natury historiozoficznej - nie budziło to nigdy wątpliwości, choć często było traktowane krytycznie, jako stawianie malarstwu zadań, których nie powinno i nie mogło realizować. W praktyce cel ów oznaczał odrzucenie faktograficznej wierności jako nadrzędnej zasady konstrukcji obrazu historycznego. Matejko rościł sobie prawo "poprawiania" rzeczywistego przebiegu, aby optymalnie przedstawić sens istotnych zjawisk i procesów, a swoistą formułę licencji artysty-wizjonera stanowią słowa, które zapisał Stanisław Tarnowski. Nie chcąc zadowolić się ilustracją jednostkowych wydarzeń, malarz wyrażał zamiar ukazania „całego procesu dążeń i zabiegów różnych ludzi, którzy nie byli obecni w tej chwili, na tym miejscu, gdzie się fakt ostatecznie dokonał"15. Ów fakt pojmował przy tym bardzo szeroko; mógł nim być np. Upadek Polski, by przywołać pierwotny tytuł dzieła, bardziej dziś znanego jako Rejtan. Malarz starał się przedstawić w syntetycznym skrócie istotne problemy dziejowe i ich uwarunkowania, a to oznaczało łączenie w jednej scenie elementów, które miały wskazać ich różnorodne czynniki i aspekty. Zgodnie z jego deklaracją tę funkcję reprezentacji pełniły najczęściej ważne postacie, a o ich umieszczeniu na płótnie rozstrzygało znaczenie merytoryczne, choćby od wydarzenia dzieliły je czas i przestrzeń. „Wtedy dopiero - podkreślał artysta - obraz historyczny będzie prawdziwie samodzielnie stworzonym, nie niewolniczą ilustracją do kroniki, ale skupieniem i odtworzeniem samodzielnym tego, co w kronikach jest rozproszone, rozrzucone a do całości faktu należy. Wtedy i malarz będzie artystycznym dziejopisem, sędzią niejako i faktu samego i wszystkich działających w nim sił i pierwiastków"16. Wynika stąd niezwykle ważna dla lektury jego dzieł ogólna dyrektywa: odstępstwa od wiedzy źródłowej o przebiegu zdarzeń nie brały się na ogół z braków wiedzy. Malarz poprzedzający swe prace szeroką erudycyjną kwerendą, "popełniał" z rozmysłem owe "błędy"; był to istotny element metody konstruowania syntezy historycznej, prezentowania układu uwarunkowań zjawisk dziejowych i szerokiego spektrum problemów epoki. W ten sposób odwoływał się także do rzeczywistości o ponadepokowym wymiarze, tworząc przesłanie historiozoficzne swej twórczości.

15. S. Tarnowski, Matejko, dz. cyt., s. 472-473.

16. S. Tarnowski, Matejko, dz. cyt., s. 472-473. 
Kazanie Skargi jest dziełem, które inauguruje ów historiozoficzny zamysł malarstwa Matejki oraz metody kodowania tego rodzaju przesłania. Program artysty wyrastał z idei epoki, które przypisywały historii moc odkrywania mądrości niezmiennie ważnej, aktualnej dla kolejnych pokoleń. Dziejopis-mędrzec, który jak w znanym wierszu Norwida potrafił zajrzeć "epokom w głąb", mógł więc zyskać status wieszcza, przewodnika narodu. Matejko malarz, zakładając cel spoza sfery czysto artystycznej, pretendując do wypowiedzenia na płótnie prawdy dziejów, dążył właśnie do takiej rangi. Wartości estetyczne nie były dlań samoistnym celem, a fakt, że jego kompozycje historyczne przynależą do dwóch odrębnych porządków, określa specyfikę ich recepcji. Warunek pełnienia roli wizjonera, odkrywającego narodowi prawdę jego historii i posłannictwa, stanowiła zdolność nawiązania pogłębionego dialogu z widzem, co wymagało wiedzy o wiele głębszej niż ta, która wystarczała odbiorcy mniej czy bardziej banalnych malowanych anegdot z przeszłości. Matejko odwoływał się zatem nie tylko do obiegowych wyobrażeń, ale też często do nieznanych szerszemu ogółowi opracowań badaczy; w dużym stopniu na takiej wiedzy opierały się złożone układy relacji między bohaterami jego obrazów. W ten sposób, ale także wykorzystując tradycję literacko-mityczną i uniwersalną symbolikę, określał ich role i przedstawiał osąd przeszłości, toteż obrazy jego "głównego cyklu" dziejów Polski stanowią nader rozbudowane łamigłówki. Malarz sięgał nieraz po znaczące detale, których funkcje można zrozumieć tylko w oparciu o zaawansowaną źródłową erudycję $e^{17}$ - wydaje się on oczekiwać od widza zadania sobie trudu stosownych poszukiwań.

Malarska narracja mająca służyć tym celom musiała odznaczać się dużo wyższym poziomem złożoności niż to, co oferowała tradycja malarstwa "wielkotematowego", które znało sposoby, pozwalające wychodzić poza statyczny układ i sugerować widzom, co było wcześniej i co stanie się za chwilę, by tworząc namiastkę temporalnej rozciągłości wyobrażonego zdarzenia, przełamywać aprocesualny z natury rzeczy wymiar przedstawień w sztukach plastycznych. Do celów Matejki nie wystarczała inwencja w stosowaniu tego typu prostych chwytów, które nadają scenie swoistą dynamikę, wskazując widzowi, że oto np. włócznia i topór za moment pozbawią życia osobę Wielkiego

17. W obrazie Matejki istotne znaczenie ma nawet to, że z kieszeni bohatera (poseł Suchorzewski w Konstytucji 3. Maja) wypada talia kart; sens tego epizodu wnikliwie odczytał Krawczyk (Matejko i historia, dz. cyt., s. 55-56). 
Mistrza pod Grunwaldem, czy że protest Rejtana zostanie złamany i nic już nie stanie na przeszkodzie podpisania aktu rozbioru. Wyobrażając w ten sposób przebieg zdarzeń, malarz-historiozof usiłował odnosić się zarazem do istotnych kwestii dziejów; pytał o przyczyny i wskazywał alternatywne możliwości, by stworzyć rozbudowany dyskurs na paru poziomach. Obrazowanie tego typu, charakterystyczne dla dzieł "głównego cyklu", których problematyka obejmuje szeroki zasięg czasowy i merytoryczny, oznacza szczególną, nieczęsto spotykaną w ówczesnym malarstwie historycznym, złożoność narracji.

W tym miejscu ta ogólna refleksja wokół narracji i sposobu budowania znaczeń i ocen przez Matejkę musi być siłą rzeczy ograniczona i uproszczona - fundamentalne obserwacje w tej kwestii zawarł w cytowanej pracy Krawczyk. Ich swoistą kwintesencję stanowi formuła, że ten "naderudycyjny" malarz-historyk, zaprojektował dla swych dzieł "naderudycyjnego" widza ${ }^{18}$. Takim widzem może być, rzecz jasna, tylko ktoś, kto zada sobie trud poszukiwań i komu starczy wytrwałości i kompetencji, by poddać refleksji drogę inspiracji artysty oraz prześledzić jego dostęp do wiedzy historycznej, co wobec niedostatku odnośnych informacji źródłowych może być zresztą na ogół tylko polem domniemań. Krótko mówiąc, warunki te może właściwie spełnić tylko wyspecjalizowany badacz, a efekty jego dociekań mogą pośredniczyć w recepcji dzieła przez szerszą widownię. Za paradoks może uchodzić fakt, że mimo nieustającej przez ponad wiek niezwykłej popularności malarstwa Matejki, takie opracowania wtedy w zasadzie nie powstawały. Jego kompozycje interpretowano na poziomie dalekim od wskazywanych tu subtelności; odwoływano się raczej do prostych emocji i stereotypów oraz obiegowej wiedzy. Z tej perspektywy można by więc ogłosić porażkę programu artysty, gdyby nie to, że nie ma podstaw sądzić, by nie przewidywał on również takiej mniej wyrafinowanej recepcji swych dzieł. Sam zresztą przecież odwoływał się do takich emocji i stereotypów oraz tworzył je, bez wątpienia zatem również owa przeważająca część widowni, na której erudycję i determinację w dążeniu do odkrywania tajemnic swoich obrazów nie mógł liczyć, stanowiła obiekt jego świadomych artystycznych zabiegów.

18. Zob. J. Krawczyk, Matejko i historia, dz. cyt., s. 125. 


\section{3. "Całość dziejowego wypadku" w obrazie}

W każdym razie względnie pełne odczytanie przesłania dzieł artysty jest niemożliwe, jeśli nie uwzględni się funkcjonującego w jego epoce maksymalnie szerokiego kontekstu wyobrażeń oraz ówczesnej wiedzy historycznej o podjętej w nich problematyce. Ta konstatacja może się wydawać mało kontrowersyjna, ale (jak już wskazywałem na wstępie) dawniejsi autorzy nie kierowali się nią bynajmniej w swych refleksjach. Zgodne z nią są zaś założenia i praktyka badawcza Krawczyka, który interpretację Skargi oparł na szeregu szczegółowych ustaleń i uzasadnionych domniemań w tym zakresie. Przyjmując, że przedstawiona scena odsyła do problematyki religijno-ideowej i politycznej Kazań sejmowych, do zawartych tam orzeczeń o władzy państwowej i obowiązkach obywatelskich ${ }^{19}$, autor nie powiedział niczego nowego. Jednak fakt, że malarz umieścił w centralnej scenie Zygmunta III obok przywódców rokoszu, skłonił go do odniesienia treści obrazu do zmagań wolności z absolutyzmem, która miała fundamentalne znaczenie dla dziejów Polski przełomu XVI i XVII wieku, a także w sporach historycznych epoki zaborów - i to jest nowością w jego interpretacji.

Autor uznał też, że zgodnie ze swą koncepcją artysta przedstawił w obrazie "całość dziejowego wypadku", która obejmuje wydarzenia z lat $1596-1607^{20}$, przy czym terminus a quo to data unii brzeskiej, a terminus ad quem - rok pokonania rokoszu. Do unii malarz odwołał się czytelnie: ukazany został jej główny promotor po stronie prawosławia, bp Hipacy Pociej oraz, być może, inny jej współtwórca i hierarcha, Cyryl Terlecki²1. Krawczyk nie wykorzystał jednak w swej interpretacji potencjału historiozoficznego, jaki niesie ta sprawa; właściwie ograniczył się do usytuowania tych postaci w obozie króla ${ }^{22}$. Skupienie niemal całej uwagi na konflikcie "tronu z narodem", oparte na słusznej skądinąd tezie, że w czasie malowania obrazu rokosz

19. Zob. J. Krawczyk, Matejko i historia, dz. cyt., s. 84. Skarga głosił homilie podczas uroczystych nabożeństw na rozpoczęcie obrad sejmu, ale teksty zawarte w zbiorze Kazań sejmowych nie są ich zapisem.

20. J. Krawczyk, Matejko i historia, dz. cyt., s. 94, 106.

21. O Terleckim pisze Krawczyk (Matejko i historia, dz. cyt., s. 101, 103), natomiast tekst towarzyszący pierwszej wystawie obrazu wymienia „dwóch biskupów unickich", ale nazywa tylko "Hipacego Pocieja, metropolitę" (Księdza Piotra Skargi kazanie przepowiadające upadek Polski, Kraków 1864). Nie jest też pewne, która postać jest drugim biskupem - być może to ta, której jedynie niewyraźny zarys głowy widać obok Pocieja.

22. Zob. J. Krawczyk, Matejko i historia, dz. cyt., s. 101, 103-104. 
był idealnym przedmiotem „ideologicznej aktualizacji"23, robi wrażenie, jakby tylko to miało tworzyć tę "całość dziejowego wypadku". Ponadto autor usiłuje wiązać przesłanie obrazu, które buduje wokół wypowiadanego przez Skargę proroctwa upadku, z powracającym w twórczości artysty motywem utraty przez Polskę dziejowych szans ${ }^{24}$, ale nie daje odpowiedzi na pytanie, o jaką szansę może tu chodzić. Można byłoby łączyć ją z tezą, że zwycięstwo nad rokoszem stworzyło warunki naprawy ustroju, owej ujętej w artykułach henrykowskich „zgubnej formy” (by przywołać formułę Józefa Szujskiego), winnej narastania anarchii, kryzysu państwa, a ostatecznie jego unicestwienia. W tym duchu wypowiadało się mniej czy bardziej otwarcie wielu historyków, ale Krawczyk nie przywołuje tych ocen, a byłoby to też niespójne z innymi jego supozycjami. Jeśli bowiem Skarga Matejki miałby wyrażać sankcję dla takich działań, to reprezentowałby stanowisko jednej ze stron konfliktu, zaś jako prorok, a więc napominający Polaków głos samego Boga, winien być - jak podkreśla autor - stojącą ponad podziałami, niekontrowersyjną postacią ${ }^{25}$.

Wymiar historiozoficzny sprawy unii wyznań wynika z często wyrażanego przekonania, że był to istotny element posłannictwa cywilizacyjnego Polski na Wschodzie, a idea ta stanowiła w XIX wieku oś ogólnej refleksji nad dziejami narodu. Głoszono przy tym nieraz, że misja ta nie została ostatecznie wypełniona, upatrując w tym przyczynę upadku państwa. Ocena ta wynikała stąd, że terytorialnego zakresu owej misji nie ograniczano na ogół do ziem Litwy i Rusi, uznając, że Polska powinna była ucywilizować w prawdziwie chrześcijańskim duchu również Północ, Moskwę, a tym samym pozbawić jej politykę opartego na brutalnej przemocy imperialnego wektora. (Prawosławie, integralnie wpisane w zbrodniczy system caratu i ślepo mu służące, uznawano powszechnie za fałszywą religię, która odrzuciła istotne wartości ewangeliczne) ${ }^{26}$. Jednakże w kwestii, czy realizacja idei unii politycznej

23. J. Krawczyk, Matejko i historia, dz. cyt., s. 108-109.

24. Tak o idei obrazu pisał sekretarz artysty Marian Gorzkowski (Wskazówki do dawniejszego obrazu Jana Matejki "Kazanie Skargi”, Kraków 1883, s. 6); por. J. Krawczyk, Matejko i historia, dz. cyt., s. 94-95.

25. Zob. J. Krawczyk, Matejko i historia, dz. cyt., s. 87-88.

26. Istotny wpływ na ówczesną żywotność tej problematyki miała (prócz, rzecz jasna, jej aktualności politycznej) historiozofia poetów-wieszczów: Krasińskiego (wyrażona m.in. w Psalmie dobrej woli i traktacie O stanowisku Polski z Bożych i ludzkich względów), a zwłaszcza Mickiewicza, głoszona szczególnie w Prelekcjach paryskich. Warto tu wskazać uznawanie unii Polski z Litwą za "figurę" przyszłego dobrowolnego zjednoczenia wszystkich narodów świata oraz ideę antytezy Polski 
i eksportu instytucji wolnościowych z Polski do Moskwy winna także objąć unię religijną, wyrażano sprzeczne opinie. W kręgach demokratycznych, uważających kontrreformacyjny Kościół za wroga ustroju Rzeczpospolitej i wszelkich swobód, głoszono wręcz, że dążenia do unii z prawosławiem stały w sprzeczności z tą misją wolności. Uważano przy tym, że warunkiem takiego przeobrażenia Moskwy było jej podporządkowanie Rzeczpospolitej, bardzo realne, jak wierzono, w czasach Stefana Batorego i Zygmunta III. Obalenie tyranii carów drogą akcji zbrojnej z zewnątrz wydawało się koniecznym warunkiem wszelkich zmian - twierdzono z reguły, że polityka papiestwa, usiłująca skłonić Rosję do dobrowolnej unii z Kościołem katolickim, była naiwna i z góry skazana na klęskę, a zarazem nie pozwoliła wykorzystać Polsce ówczesnej przewagi.

Sprawę utraconej w tym czasie szansy pokonania Rosji Matejko podejmie w czytelnej formie w Batorym, ale jest ona obecna już we wcześniejszym Skardze, gdzie ukazał on Jerzego Mniszcha i Jana Piotra Sapiehę, wybitnych uczestników interwencji po stronie fałszywych pretendentów do tronu carów, współczesnej rokoszowi. Postacie te nie zajmuja pierwszoplanowego miejsca, ale zdarza się często, że właśnie osoby i detale z marginesu czy drugiego planu są w dziełach Matejki medium istotnych znaczeń ${ }^{27}$. W dotychczasowych interpretacjach je ignorowano, a tym samym nie dostrzeżono fundamentalnego problemu obrazu, który poprzez nie wyrażał malarz.

\section{Bohaterowie obrazu - wątpliwości}

"Skład osobowy" w Kazaniu Skargi nie jest sprawą oczywistą, wymaga pewnych dociekań i uściśleń, chociaż pierwszej wystawie dzieła towarzyszyła

\footnotetext{
i Rosji jako upostaciowań dziejowego dobra i zła. Na zdecydowany opór napotykała natomiast myśl poety o pogodzeniu sprzeczności ich dziejowych ról (odwoływał się do tego, o czym niżej, Matejko). O poglądach ważniejszych historyków na te kwestie piszę w dalszym ciągu rozprawy.

27. Podkreśla to Krawczyk (Matejko i historia, dz. cyt., s. 81), ale nie rozważa roli Mniszcha i Sapiehy w Skardze, a nawet ich nie identyfikuje, prezentując obrys postaci (Matejko i historia, dz. cyt., s. 98). Jako przykłady autor podawał marginalne figury komtura von Plauen w Grunwaldzie czy chłopa i Żyda w Konstytucji 3-Maja (Matejko i historia, dz. cyt., s. 132-133, 171-200). Malarz nieraz powierzał funkcje nośnika ważnych znaczeń dalekim od pierwszego planu elementom i postaciom; szczególny jest przykład Hołdu Pruskiego, gdzie istotę przesłania konstytuują: gołębica - symbol Ducha Świętego, sentencja z listu św. Pawła na ramie i autoportret malarza jako Berrecciego (H. M. Słoczyński, „Hołd Pruski” Jana Matejki, w: Czas i wyobraźnia. Studia nad plastyczna i literacka interpretacją dziejów, red. M. Kitowska-Łysiak, Lublin 1996, s. 202-208, 234-237).
} 
objaśniająca personalia publikacja. Ta jednak składa się z dwóch części, a informacje w nich zawarte są nie zawsze zgodne. Gdy jedna z lakonicznych notek prezentujących postacie obrazu wymienia "Aleksandra Sapiehę, starostę uświatskiego", który "z kniaziem Rożyńskim popierał obu fałszywych Dymitrów", to dołączona litografia z podpisanymi głowami postaci informuje, że jest to Jan Paweł Sapieha ${ }^{28}$. W obu przypadkach imiona są błędne, co stanowi poważny szkopuł, bo wolno było przyjąć, iż artysta miał kontrolę nad treścią tekstu, którego celem było ukierunkować recepcję dzieła. Ta pomyłka da się akurat sprostować w sposób wykluczający wątpliwości: przesądza tu wskazana rola Sapiehy w dziejach interwencji w carstwie moskiewskim i wspomniane starostwo, nagroda za zasługi w bitwie pod Kircholmem. Zamienić imię Jan Piotr na Jan Paweł było nietrudno, jeśli mylili się też historycy ${ }^{29}$ (mógł to powodować fakt, że ojcem bohatera był Paweł, a synem - Paweł Jan, później bez wątpienia najbardziej z nich znany dzięki Potopowi Sienkiewicza). Warto dodać, że zaufany sekretarz Matejki, Marian Gorzkowski, który swe Wskazówki do obrazu pisał po latach bez wątpienia na podstawie rozmów z jego twórca, prawidłowo podał imię starosty uświackiego ${ }^{30}$. Nie ma tu potrzeby dociekać, skąd pojawiło się imię Aleksander, ale nie sposób sobie wyobrazić, by za obiema wersjami imienia jednej osoby w składającej się tylko z 2 (!) kartek publikacji, stał sam artysta - bez wątpienia otrzymane od niego informacje zniekształcono w druku.

Podobnie tylko w taki sposób można wyjaśnić kolejną pomyłkę. Określony w objaśnieniu jako oparty o krzesło królewskie, po prawej książę Janusz Ostrogski, kasztelan krakowski, pośrednik między królem a rokoszanami, w litografii został nazwany Januszem Zborowskim, wojewodą bracławskim. I tu również o identyfikacji postaci powinna przesądzać jej wskazana w objaśnieniu rola, ściśle związana z tematem obrazu i uzasadniająca jej obecność na płótnie. Tego nie da się powiedzieć o alternatywnej możliwości, Januszu Zborowskim; co więcej, nikt pośród przedstawicieli potężnego pod koniec XVI wieku rodu nie nosił tego imienia, zaś wojewodą bracławskim był w latach 1576-1608 Janusz Zbaraski. Jego obecność w obrazie nie mogłaby dziwić: w czasie rokoszu był on bowiem dowódcą oddziału pełniącego straż

28. Księdza Piotra Skargi kazanie..., dz. cyt.

29. Por. M. Dzieduszycki, Piotr Skarga i jego wiek, t. 2, Kraków 1850, s. 339-340.

30. M. Gorzkowski, Wskazówki..., dz. cyt., s. 11. 
przy królu ${ }^{31}$. Charakter tych pomyłek wskazuje, że za nieścisłości w tekście towarzyszącym wystawie nie odpowiada Matejko: jeśli mógł on zamienić imię Jan Piotr na Jan Paweł, jak czynili inni, to nie mógł nie wiedzieć, kogo przedstawił w przełomowej dla swej twórczości kompozycji ${ }^{32}$.

\section{5. Źródła wiedzy artysty o epoce}

Wydaje się, że choć nie zachowały się żadne bezpośrednie dane, w przypadku Skargi można z dużym prawdopodobieństwem wskazać niektóre ważne źródła wiedzy artysty o zobrazowanej problematyce dziejowej. Trzeba podkreślić, że jakkolwiek dorobek polskiej historiografii był wtedy jeszcze relatywnie bardzo ubogi, to dziejami przełomu XVI i XVII wieku zajmowano się wyjątkowo często. Rozumiano bowiem znaczenie rokoszu i interwencji w Moskwie i podzielano przekonanie, że w epoce potęgi państwa, po której szybko nastąpiły czasy kryzysu, należy szukać przyczyn tego niekorzystnego zwrotu ${ }^{33}$. W centrum uwagi znalazła się wtedy również znacząca rola jezuitów, a osobne miejsce zajmowała postać Skargi i zawarte w jego kazaniach ostrzeżenia przed katastrofą Polski. Jeśli artysta nadał tej postaci rangę autorytetu polityczno-moralnego czy wręcz medium, przez które przemawiał Bóg, to trzeba pamiętać, że dotarcie z tą wizją do szerszej opinii ułatwiał, a być może nawet warunkował, obraz proroka, a zarazem uosobienia polskości, ukazany z katedry w Sorbonie przez Adama Mickiewicza ${ }^{34}$. Stanowisko poety-wieszcza bez wątpienia osłabiło w odbiorze jakiejś części Polaków odium, które spadło na królewskiego kaznodzieję jako szermierza dążeń Towarzystwa Jezusowego, potępianego wtedy niezwykle często jako istotny (a nieraz wręcz najważniejszy) czynnik sprawczy upadku Polski35. (Pozytywną

31. Zob. J. Szujski, Dzieje Polski, t. 3, w: J. Szujski, Dzieła, seria 2, t. 3, Kraków 1894, S. 210.

32. Należy jednak dodać, że Janusza Zborowskiego wymienił po 20 latach Gorzkowski (Wskazówki..., dz. cyt., s. 12).

33. Szujski pisał, że w tej epoce "największe klęski w bliskiem z dniami chwały stoją w sąsiedztwie" (Dzieje Polski, dz. cyt., t. 3, s. 9).

34. A. Mickiewicz, Literatura słowiańska, w: A. Mickiewicz, Dzieła, t. 8, Warszawa 1997, s. 567-582. W jego słynnym wykładzie XL kursu pierwszego znalazły się m.in. te słowa: „Skarga nie jest przedstawicielem jednego stronnictwa ani jednej epoki; ogarnia on sobą cały kraj, cały naród, z jego przeszłością, teraźniejszością, a nawet przyszłością. Rodziną jego jest Polska" (Literatura słowiańska, dz. cyt., s. 568).

35. Te powszechne oceny stanowią ważny fenomen, zasługujący na monografię; ich przykłady przedstawiłem w: H. M. Słoczyński, Światło w dziejarskiej ciemnicy. Koncepcja dziejów i interpretacja przeszłości Polski Joachima Lelewela, Kraków 2010 , s. $546-553$. 
ocenę i rangę dzieła Skargi oczywiście podkreślali wcześniej autorzy z kręgu Kościoła, jak choćby Jan Paweł Woronicz).

Trudno sobie wyobrazić, by artysta nie sięgnął po wydane stosunkowo niedawno dzieło Piotr Skarga i jego wiek ${ }^{36}$, w którym Maurycy Dzieduszycki nie tylko wznosił pomnik tytułowej postaci, ale podjął też zdecydowaną próbę rehabilitacji zakonu. Wolno zakładać, że znał on także dzieło Henryka Schmitta Rokosz Zebrzydowskiego, wydane ledwie kilka lat wcześniej, a prezentujące ogląd dziejów zupełnie różny od poprzedniego ${ }^{37}$. Obowiązkową lekturą każdego zainteresowanego historią było w okresie przed powstaniem świeżo wydane Słowo dziejów polskich Waleriana Wróblewskiego (Koronowicza $)^{38}$, popularny wykład idei posłannictwa narodowego, połączony z elementami panslawizmu (te ostatnie miały zaznaczyć się wyraźnie w późniejszej twórczości Matejki). Jego autor poświęcił wiele miejsca sprawie zmarnowania szans zaszczepienia polskiej wolności w Moskwie pod koniec XVI i na początku XVII wieku. Z dużym prawdopodobieństwem można też sądzić, że artysta czytał dzieła dawniejsze: Juliana Ursyna Niemcewicza Dzieje panowania Zygmunta III ${ }^{39}$ i Adama Naruszewicza Historię Jana Karola Chodkiewicza ${ }^{40}$. Znał też zapewne biografie Lwa i Jana Piotra Sapiehów, autorstwa Kazimierza Kognowickiego, które przywołał we Wskazówkach do obrazu Gorzkowski ${ }^{41}$.

O pewności lektury można zaś mówić w przypadku Śpiewów historycznych Niemcewicza, choć brak świadectw, że ta łączyła się z pracą nad Skargą. Wiadomo jednak, że było to źródło pierwotnych wyobrażeń przyszłego artysty o dziejach Polski, który w dzieciństwie kopiował ryciny ilustrujące zawarte w nim wierszowane epizody. Ze Śsiewów, a raczej z tworzących ich erudycyjne tło Przydatków do nich, dowiedział się być może po raz pierwszy, jak wielką szansę utraciła Polska za sprawą Zygmunta Wazy, władcy "niezdolnego do żadnego męskiego dzieła", który nie potrafił pozyskać korony carów ani dla siebie, ani dla syna, "a przez to nie tylko dla krwi własnej wielkiego nie pozyskał państwa, ale i w późniejszych czasach ostatniej klęski naszej [tzn.

36. M. Dzieduszycki, Piotr Skarga i jego wiek, t. 1-2, Kraków 1850.

37. H. Schmitt, Rokosz Zebrzydowskiego, Lwów 1858.

38. W. Koronowicz [Wróblewski], Słowo dziejów polskich, t. 1-2, Lipsk 1858, t. 3, Lipsk 1860.

39. J. U. Niemcewicz, Dzieje panowania Zygmunta III, t. 1-3, Kraków 1860.

40. Ostatnia wtedy edycja nosiła tytuł Żywot Jana Karola Chodkiewicza (t. 1-2, Kraków 1858).

41. M. Gorzkowski, Wskazówki..., dz. cyt., s. 11. 
upadku państwa polskiego] stał się powodem"42. Drugim dziełem, znanym Matejce ponad wszelką wątpliwość, a co więcej powstającym - by tak rzec na jego oczach, i to w okresie pracy nad Skarga, jest trzeci tom Dziejów Polski Józefa Szujskiego. Wiadomo, że artysta czytał wszystko, co napisał młody poeta i publicysta ${ }^{43}$, który dopiero wyrastał na wielkiej klasy historyka, a był wtedy jego bliskim przyjacielem. Wkrótce zostanie on bodaj jedynym obrońcą tak krytycznie przez ogół rodaków przyjętego Upadku Polski, a jest też co najmniej prawdopodobne, że wpłynął znacząco na jego przesłanie ${ }^{44}$. Łatwo również wykazać, że jego prace i poglądy inspirowały późniejsze dzieła artysty, Kościuszkę pod Racławicami i Hołd Pruski ${ }^{45}$. W tym ostatnim uwiecznił on twarz dawnego przyjaciela, a po jego rychłej śmierci zdobył się na patetyczny gest, wkładając na głowę leżącego w trumnie wieniec laurowy.

Refleksja wokół przesłania dzieł Matejki nie może się więc obejść bez odniesienia ich treści do poglądów historycznych Szujskiego, co też znalazło się w centrum uwagi Krawczyka. Ale jeśli Kazanie Skargi ma być syntezą problematyki dziejów Polski przełomu XVI/XVII wieku, to wskazówek do jego odczytania trzeba szukać w tym, co pisał w tej kwestii przyjaciel artysty akurat wtedy, gdy krystalizowała się koncepcja dzieła. Cytowany autor nie dokonał jednak stosownej konfrontacji i nie zauważył zbieżności istotnych wątków Skargi z treścią odpowiednich partii Dziejów Polski Szujskiego. A można tam

42. J. U. Niemcewicz, Śpiewy historyczne, Kraków 1835, s. 316, por. także 320, 325, 328.

43. Zob. I. Jabłoński-Pawłowicz, Wspomnienia o Janie Matejce, Lwów 1912, s. 59; autor wspomnień, kolega szkolny artysty, pisał też o młodzieńczej rywalizacji obu twórców: „kto więcej zdoła dla dobra Ojczyzny zdziałać" (Wspomnienia..., dz. cyt. s. 59).

44. Por. H. M. Słoczyński, "Policzkować trupa matki się nie godzi...". Józef I. Kraszewski przeciw "Upadkowi Polski" Jana Matejki, "Literacje" 2012 nr 3 (26), s. 11-17. O bliskości ich ówczesnych relacji świadczy też to, że Szujski miał zostać ojcem chrzestnym córki Matejki, nie mógł jednak dojechać na ceremonię (S. Serafińska, Jan Matejko. Wspomnienia rodzinne, Kraków 1958, s. 211-212).

45. Pierwsze z dzieł nawiązuje do bardzo wtedy popularnej sztuki teatralnej Władysława L. Anczyca Kościuszko pod Racławicami, opartej w dużej części na motywach wczesnego opowiadania Szujskiego Ostatnia nobilitacja (H. M. Słoczyński, Racławice $i$ cud odzyskania niepodległości. Historiozoficzne przesłanie Jana Matejki, w: Powstanie Kościuszkowskie i jego Naczelnik. Historia i tradycja, red. M. Frančić i T. Kulak, Kraków 1996, s. 227-232). Dla genezy drugiego ważne znaczenie miał wiersz Stańczyk, prolog do dramatu Szujskiego Kopernik, co zauważył już dawniej Julian Krzyżanowski (Błazen starego króla, w: J. Krzyżanowski, W wieku Reja i Stańczyka, Warszawa 1958, s. 380). O miejscu poglądów Szujskiego w strukturze znaczeniowej tej kompozycji zob. H. M. Słoczyński, "Hołd Pruski"..., dz. cyt., s. 222-229 oraz H. M. Słoczyński, Król bez berła. "Hołd Pruski" Jana Matejki a mesjanistyczny ideał ustroju Polski, w: Symbole władzy - władza symboli, pod red. M. Dyras, B. Suchoń-Chmiel i T. Kwoki, Kraków 2014, s. 313-314, 317-318. 
odnaleźć istotne sugestie, a ponadto formułę, która kojarzy się z refleksją malarza o łączeniu procesów i zdarzeń w jedną całość. Oto historyk uznał, że rok 1606 był „charakterystyczną chwilą dziejową", co oznaczało dlań ewidentnie taką, w której kumulują się główne problemy epoki. Wtedy to bowiem miały ujawnić się w pełni „ujemne strony politycznego i społecznego ustroju narodu", a to w postaci rokoszu i „sprawy Dymitra". Tę drugą nazwał "wyskokiem tej wygórowanej możnowładczej ambicji, która nie znając granic, nie znała i obowiązków patriotycznych"46. Będę próbował pokazać, iż Matejko ukazał tę samą "chwilę dziejową" i te same najbardziej znamienne zjawiska owego czasu, o których pisał Szujski. Przedstawię także przesłanki oceny, że był on skłonny uważać skutki ówczesnych działań i zaniechań za utratę szansy na wypełnienie powierzonej przez Opatrzność misji wobec Rosji, a karą za to były późniejsze losy narodu i jego aktualna kondycja.

\section{Skarga - głos Boga napominający rokoszan i króla}

Bez wątpienia ma rację Krawczyk, uznając, że Skarga Matejki to prorok w ścisłym znaczeniu tego pojęcia - ten, przez kogo „żywe słowo boże" osądza przeszłość Polski, napomina elity państwa i zapowiada przyszłośćc7 ${ }^{47}$ O tym, że idzie tu o proroctwo przyszłości, mówi pełny tytuł obrazu, znany z towarzyszącej pierwszej wystawie publikacji: Księdza Piotra Skargi kazanie przepowiadajace upadek Polski. Ale i bez tej informacji jest oczywiste, że artysta odwołał się właśnie do tego, do jądra patriotycznej legendy bohatera. Tym samym zostały przywołane Kazania sejmowe, gdzie ta przepowiednia była wypowiadana z potężną siłą wyrazu, przy czym kaznodzieja naśladował styl proroków Starego Testamentu, wzywających lud Izraela do nawrócenia i odwołał się wprost do Izajasza i Jeremiasza. Tekst towarzyszący pierwszej wystawie cytował fragment Wzywania do pokuty obywateli Korony Polskiej, który nawiązywał do Izajasza, a zawierał słowa: „ustawicznie się mury rzpltej waszej rysują, a wy mówicie: nic, nic. Nierządem stoi Polska! Lecz gdy się nie spodziejecie, upadnie i was wszystkich potłucze..." ${ }^{48}$.

46. J. Szujski, Dzieje Polski, dz. cyt., t. 3, s. 211-212.

47. J. Krawczyk, Matejko i historia, dz. cyt., s. 92.

48. Księdza Piotra Skargi kazanie..., dz. cyt.; P. Skarga, Kazania sejmowe, także Wzywanie do pokuty obywatelów Korony Polskiej, wydanie K. J. Turowskiego, Kraków 1857, s. 143. Jest to jedno z proroctw Skargi, które cytował Mickiewicz (Literatura słowiańska, dz. cyt., s. 578). 
Nie ulega wątpliwości, że artysta widział w Skardze nie tego, kto zagrożenia rysujące się w sferze polityki odgadł swym ziemskim rozumem, lecz proroka, który piętnował grzechy narodu i zapowiadał karę dzięki darowi widzenia danemu od Boga. Krawczyk trafnie łączy intencje przydania nadprzyrodzonej siły jego słowu z usytuowaniem na tle konfesji św. Stanisława, co przywołuje średniowieczną legendę o męczeństwie patrona Polski. Mówi ona o winie narodu i nałożonej na niego karze w postaci rozczłonkowania Królestwa Piastów, ale też o pokucie, o wybaczeniu grzechu i cofnięciu karzącej ręki Boga ${ }^{49}$. Ukazanie Skargi jako proroka par excellence wpisywało się zarazem w tradycję romantyczną - fundamentalne znaczenie miało zwłaszcza dla wizji historii stworzonej na gruncie mesjanizmu. Głosiła ona, że Opatrzność objawia plan dziejów wybranej jednostce, powierzając jej misję wskazywania ludowi drogi współdziałania z jej wolą. Właśnie w tym duchu sylwetkę Skargi nakreślił Mickiewicz, który mówił z katedry Collége de France, że ten „ponad wszystkich mówców wznosi się szczególnym darem niebios, darem proroczym". Przekonanie, że królewskiemu kaznodziei "przyszłość staje przed oczyma jak otwarta dziejów księga, a on wszystkie jej karty przebiega i opowiada", skłoniło nawet poetę, by stawiać go ponad wyrażających się dwuznacznie proroków Izraela ${ }^{50}$.

Artystyczna przyszłość Matejki pokazała jasno, jak bliska była mu idea sztuki proroczej. Nie ulega wątpliwości, że uważał siebie za następcę wieszczów, a swą twórczość - za rewelację głębokiej prawdy dziejów. Ewidentną próbą ukazania obrazu przeszłości z perspektywy misji Polski w ramach boskiego planu historii są zwłaszcza Hołd Pruski i Wernyhora, przy czym to drugie dzieło ma czytelną strukturę proroctwa: nie tylko przedstawia przepowiednię tytułowej postaci, ale zapowiada "od siebie" nawiązujący do jej treści przyszły triumf Polski. Uważam, że postrzeganie Skargi z kompozycji Matejki jako proroka w pełnym sensie tego słowa, wymaga szukania związku jej przesłania z całościową problematyką dziejową. Wobec tego skupienie się na kwestii sporu "regalistów" ze szlachecką opozycją, jak to czyni Krawczyk, zawęża w istocie rolę bohatera do promowania konkretnych rozwiązań ustrojowych, a przez to wbrew deklarowanej przez autora intencji - faktycznie obniża jego rangę.

Konstatując konieczność szerszego spojrzenia na problematykę obrazu, nie próbuję wcale pomniejszać wagi rokoszu w jego strukturze znaczeniowej.

49. Por. J. Krawczyk, Matejko i historia, dz. cyt., s. 113-116.

50. A. Mickiewicz, Literatura słowiańska, dz. cyt., s. 581, 576. 
Przeciwstawienie kaznodziei przywódcom ruchu jest dobitne, co oddaje zarówno sądy historycznego Skargi o nich, jak i ich reakcję na jego słowa i zabiegi. Jak pisał jego biograf, dla rokoszan był on „najgłówniejszym burzycielem Rzeczpospolitej", a sam Zebrzydowski oskarżał go, że jest narzędziem Austrii ${ }^{51}$. Autor ten odnotował również, że na burzliwym sejmie 1606 roku, który poprzedzał otwarty bunt szlachty, Skarga wzywał z ambony do zgody i wspólnego działania ku ocaleniu ojczyzny od upadku, ale „Janusz Radziwiłł, Stadnicki i Gorajski mieli niebawem mowy, które zakłóciły sejm cały"52. Matejko ukazał dwóch spośród sprawców zaburzenia, obok zaś głównego przywódcę rokoszu, wojewodę krakowskiego Mikołaja Zebrzydowskiego. Ten nie pojawił się wśród burzycieli obrad sejmowych, bo choć był od początku spiritus movens eskalacji konfliktu, wolał wtedy pociągać za sznurki z ukrycia i także później pozorował umiar w działaniu ${ }^{53}$. Zebrzydowski, wychowanek kolegium w Braniewie, utrzymywał przy tym bliskie związki z jezuitami; gorliwie uczestniczył w inicjatywach charytatywnych zakonu i współdziałał na tym polu z ich głównym promotorem - Skargą. Król mógł więc wierzyć, że kaznodzieja potrafi skutecznie przemówić do sumienia butnego magnata, gdy ten gotował się już wyraźnie do podniesienia sztandaru buntu. Jego autorytet jednak nie wystarczył - pojednawcze poselstwo z ramienia króla nie powiodło się i zamiast wojewodę "skruszyć, w większą wbiło go pychę, i nie jako senator, ale jak ten, w którego rękach złożony jest los ojczyzny, odpowiedział..." ${ }^{54}$. Warto tu zwrócić uwagę na paradoksalność powstałej sytuacji: w obawie o likwidację wolności wyznania, którą uważano za środek czy etap planu instalacji absolutum dominium, formułowano żądania, których spełnienie naruszałoby tę wolność: domagano się likwidacji fundacji na rzecz jezuitów i ograniczenia ich działalności ${ }^{55}$. A przy tym wszystkim przywódcą ruchu był gorliwy katolik i hojny uczestnik dzieł miłosierdzia, które firmował zakon.

51. M. Dzieduszycki, Piotr Skarga..., dz. cyt., t. 2, s. 419, 389.

52. M. Dzieduszycki, Piotr Skarga..., dz. cyt., t. 2, s. 383.

53. Dawniejsi autorzy eksponowali osobistą pychę wojewody krakowskiego i powstałą na tym tle osobistą urazę do króla jako przyczynę rokoszu. Choć więc obrońcy rokoszu, jak Schmitt, przekonywali o „nieskazitelności” jego charakteru (Rokosz..., dz. cyt., s. 76), to zachowała raczej ważność ocena, że jego imię „żyje w przekleństwie wieków" (T. Czacki, O litewskich i polskich prawach, t. 1, Kraków 1861, s. 43).

54. M. Dzieduszycki, Piotr Skarga..., dz. cyt., t. 2, s. 387-388; por. też J. Szujski, Dzieje Polski, dz. cyt., t. 3, s. 200.

55. Skarga miał więc słuszność, że rokoszanie, walcząc pod hasłem obrony wolności, żądali środków właściwych tyraniom (M. Dzieduszycki, Piotr Skarga..., dz. cyt., t. 2, s. 441-442). 
7. Skarga a Zygmunt III:

Polska w obozie katolickim i program regalistyczny

Krawczyk dostrzegł trafnie, że artysta nie potępił rokoszu jednostronnie rękawica leżąca na posadzce pomiędzy trzema przywódcami ruchu a krzesłem Zygmunta III oznacza wyzwanie, które król rzucił opozycji ${ }^{56}$ (czy raczej ogółowi szlacheckiemu). Widać też, na czym polegała ta prowokacja: obecność posłów cesarza i Hiszpanii oraz przedstawicieli Stolicy Apostolskiej wskazuje główne gravamina rokoszu, odnoszące się do kupczenia interesami Polski, do prób posłużenia się nią do realizacji celów obozu katolickiego i podporządkowania Habsburgom. Z tej grupy ustawionej konfrontacyjnie, twarzą w twarz z rokoszanami, malarz określił imiennie wysłanników papieskich: nuncjusza Klemensa VIII Germanika Malaspinę, który przedstawił projekt ligi przeciw Turkom na sejmie 1595 roku i legata Henryka Gaetano, który przybył w tym celu rok później (wtedy byli tam obecni również posłowie Habsburgów). Wcześniej Malaspina towarzyszył królowi Polski w podróży do Szwecji w celu objęcia tronu po śmierci ojca. Niemcewicz, który wyraził opinię, że za sprawą jezuitów Zygmuntem owładnął "fatalny szał nawrócenia odszczepionych królestw", podał, że zabiegał on, by na króla protestanckiego narodu koronował go właśnie nuncjusz ${ }^{57}$. Postać ta nadawała się więc idealnie, by przywołać politykę dworu, która stawiając plany obozu katolickiego ponad żywotne interesy państwa, narażała je na wojnę z Turcją, miała przynieść konflikt władcy ze szwedzkimi poddanymi, pozbawienie go dziedzicznego tronu i uwikłanie Polski w wojny z północnym sąsiadem. Gest Malaspiny położony na ustach palec, rozumiany potocznie jako wezwanie do milczenia, bez wątpienia odnosi się do tajnej dyplomacji króla, która wywołała oskarżenia, że jest on gotów oddać tron Polski Habsburgowi za pomoc w pacyfikacji i rekatolicyzacji Szwecji. Te w części udokumentowane konszachty, naruszające prawa i interesy państwa, były główną przyczyną powstania opozycji i jej pierwszego gwałtownego starcia z tronem w 1592 roku na tzw. sejmie inkwizycyjnym ${ }^{5}$. Później powszechne podejrzenia o kontynuację tej polityki stały się dla wielu główną przesłanką akcesu do rokoszu, i to właśnie ona oznaczała rzucenie wyzwania narodowi szlacheckiemu.

56. Zob. J. Krawczyk, Matejko i historia, dz. cyt., s. 111.

57. J. U. Niemcewicz, Śpiewy historyczne, dz. cyt., s. 294-296.

58. Zob. J. Szujski, Dzieje Polski, dz. cyt., t. 3, s. 156-160. 
To wszystko nie oznacza, że Matejko usprawiedliwiał oponentów władcy czy też dzielił winę między obie strony w równym stopniu. Wolno sądzić, że potępienie rokoszu jest bezwzględne - wszak historyczny Skarga, jak pisał Szujski, widział w nim początek spełniania się swojego proroctwa upadku ${ }^{59}$ i być może ten fakt stał się inicjalną ideą obrazu. Jednak wskazując przy tym odpowiedzialność króla, artysta stawia badacza przed istotną trudnością interpretacyjną. Jeśliby bowiem diagnoza zła, którą wygłasza Skarga, obejmowała Zygmunta, oznaczałoby to kolizję ze stanowiskiem historycznego Skargi, który wspierał tron w sporze z rokoszem. A przemawia za tym pokazanie reakcji króla na natchnione duchem Bożym słowa: zamknięte oczy i obojętna twarz sugerują duchową nieobecność (być może drzemkę ${ }^{60}$ ). W każdym razie widać, że nie odczuwa głęboko czy nie pojmuje ich znaczenia, jest więc niezdolny zrozumieć istotę przekazanych przestróg i terminalną powagę sytuacji dziejowej ${ }^{61}$. Byłoby to zgodne z oceną Szujskiego, który krytykę Zygmunta łączył z dobitnym potępieniem rokoszu, a sytuując skutki jego działania w perspektywie przyszłych klęsk, oceniał, że „król na dwóch stołkach siedzący, król nie patriota, król ciążący wyobrażeniami poza granice Polski i ducha polskiego, przyspieszył ten upadek sprowadzeniem nieszczęśliwych wojen, rozbratem tronu z narodem"62. Przyjmując, że artysta myślał podobnie, tłumaczy się sens rękawiczki, poniekąd jednak podważając spoistość ideową dzieła. Wprowadza to bowiem rozdźwięk pomiędzy statusem głównego bohatera jako nosiciela absolutnej prawdy a wiedzą o postawie jego historycznego pierwowzoru w jednej z ważnych kwestii. Stanowisko rzeczywistego Skargi

59. Zob. J. Szujski, Dzieje Polski, dz. cyt., t. 3, s. 198.

6o. Być może w ten sposób artysta dyskretnie polemizuje z pierwowzorem swego głównego bohatera; może to być bowiem przewrotne nawiązanie do słów kaznodziei, który w przedmowie do Kazań na niedziele i święta całego roku monarsze „porucza na piśmie to czego rad słuchał i z tak wielką ochotą, iżem nigdy w. k. mości drzymiącego na kazaniu, ani z kim gadającego nie widział" (M. Dzieduszycki, Piotr Skarga..., dz. cyt., t. 2, s. 193). Natomiast Zygmunt III Matejki, jeśli nie drzemie, to na pewno nie słucha Skargi „z wielką ochotą".

61. Poza króla może zarazem wyrażać powszechną krytykę jego izolowania się od poddanych; jeden z paszkwili oskarżał go: „on jak Hiszpan nadęty, zimny i dumny ledwie raczy półgębkiem odpowiedzieć kiedy na pytania" (M. Dzieduszycki, Piotr Skarga..., dz. cyt., t. 2, s. 362).

62. J. Szujski, Dzieje Polski, dz. cyt., t. 3, s. 181. Historyk pisał także, że król „tkwił w zaklętem kole swojej kamaryli" i że opanowali go „zupełnie” jezuici (J. Szujski, Dzieje Polski, dz. cyt., t. 3, s. 184, 161). Oceniał on wtedy negatywnie rolę zakonu, ale to nie osłabiło bezwarunkowej pochwały zasług Skargi. 
nie w każdej sprawie jest więc wyrocznią i absolutną miarą, którą należy oceniać pozostałe dramatis personae z kompozycji Matejki.

Ukazując krytycznie Zygmunta, artysta mógł mieć na względzie kwestię relacji jego polityki do ideału ustrojowego Skargi. Wyrażany nieraz w kazaniach (także sejmowych) obraz władcy chrześcijańskiego, ostro przeciwstawiany tyranii sułtana i cara, był Matejce zapewne dobrze znany. W obliczu rokoszu kaznodzieja przekonywał zebraną w Wiślicy szlachtę, iż absolutum dominium może sprawować "tylo pan Bóg, który sam w rządzie swym pobłądzić nie może". Głosił także, iż "do monarchii trudno naleźć człowieka w dobroci bezpiecznego i w rozumie nieomylnego i bez bojaźni odmiany jego na tyraństwo", zalecając ustrój mieszany z udziałem elementu arystokratycznego i demokratycznego, gdzie monarchę ograniczają "rada i prawo", aby "moc jego z brzegów nie wylewała, a w rządzie nie błądził i tyranem nie zostawał"63. Treść jego nauk nie pozostawia zarazem wątpliwości, że w Polsce nie ma groźby tyranii, a Zygmunt zabiega tylko o realne prerogatywy tronu w ramach ustroju mieszanego. Nie da się przy tym całkiem wykluczyć, że Skarga bezwzględnie potępiając postawę opozycji szlacheckiej, mógł jednak dostrzegać, że niektóre ze stawianych królowi zarzutów są uzasadnione. Nawołując mimo to do należnego mu posłuszeństwa, postępował w zgodzie z dawną tradycją Kościoła, ponieważ nie została przekroczona granica tyranii. Matejko mógł sądzić, że czyniąc to, Skarga historyczny widział w postawie króla "mniejsze zło", ale ze względów taktycznych nie chciał go wskazywać, powinien je natomiast napiętnować - obok "wielkiego zła" anarchii - idealny Skarga prorok w obrazie ${ }^{64}$. Mam rzecz jasna świadomość, że ta sugestia, która mogłaby zneutralizować sprzeczność między stanowiskiem tytułowego

63. M. Dzieduszycki, Piotr Skarga..., dz. cyt., t. 2, s. 430-431; biograf podkreśla też zbieżność tej deklaracji z treścią 6. kazania sejmowego, gdzie jezuita zastrzegał, iż „nie taką monarchią chwalimy, jaka jest u Turków, Tatar i Moskwy, która ma bezprawne panowanie, ale taką, która prawy sprawiedliwemi i radą mądrą podparta jest i moc swoje ustawami nabożnemi umiarkowaną i określoną ma". Skarga wskazał przy tym, że monarchia w Polsce otrzymała taki charakter za sprawą chrześcijaństwa, gdyż dzięki umiarkowaniu pierwotnych prerogatyw przez prawo Boże „władza się nie króciła ani kurczyła, ale miarkowała” (M. Dzieduszycki, Piotr Skarga..., dz. cyt., t. 2, s. 262-263).

64. Malarz zapewne wiedział też, że historyczny Skarga nie we wszystkim popierał króla i podobnie jak Zamoyski był przeciwny jego małżeństwu z siostrą zmarłej pierwszej żony (decydowały tu nie względy polityczne, jak u kanclerza, lecz religijne). Z tego powodu prosił nawet o zwolnienie z funkcji kaznodziei, ale sprzeciwił się temu generał zakonu, zalecając pozostawić tę sprawę do decyzji Rzymu (M. Dzieduszycki, Piotr Skarga..., dz. cyt., t. 2, s. 308-309). 
bohatera kompozycji wobec króla a postawą jego historycznego pierwowzoru, jest tylko przypuszczeniem.

Matejko ukazał również inny czynnik niezadowolenia opinii, potęgujący kontestację polityki króla: upodobania i obcość kulturową, co wyraża jego strój i poza. Zygmunt III wygląda tak, jak go widziała szlachta - jak pisał autor z paszkwilu, cytowanego w biografii Skargi, „on jak Hiszpan nadęty, zimny i dumny ledwie raczy półgębkiem odpowiedzieć kiedy na pytania"65. Istotne znaczenie w tej kwestii ma ukazanie Mikołaja Wolskiego, który jako jedyny w obrazie (prócz Zygmunta) jest ubrany z cudzoziemska. Niemcewicz pisał, że monarcha, "niedostępny zasłużonym i poważnym mężom, zamykał się z alchimistą Wolskim, starostą krzepickim" ${ }^{66}$. Opinię raziły obce mentalności szlachty zamiłowania króla, realizowane jakoby kosztem zaniedbywania spraw państwa (prócz alchemii chodziło także o grę w piłkę i w karty). Miał to władcy za złe Zebrzydowski, który, jak pisał Naruszewicz, sam był "z przyrodzenia ponury i ostrych obyczajów" ${ }^{\prime 67}$. Obecność postaci "alchimisty" nie wynika więc raczej z intencji ukazania "typowego dworaka", jak pisał Krawczyk, lecz przywołuje wspomniane zastrzeżenia, generujące niechęć do króla.

Nie do przyjęcia jest także formuła "stronnictwa dworskiego", które według tego autora miałby reprezentować Wolski obok prymasa Stanisława Karnkowskiego i hierarchów unickich. Rola dziejowa tych ostatnich (jeśli już zasadna jest tu liczba mnoga) nie upoważnia do wpisania ich do owego "stronnictwa"68 - wszak oznacza to coś innego, niż tylko bliską współpracę z tronem w kwestii unii religijnej. Trudno też uzasadnić przyznanie takiego miejsca Karnkowskiemu: wprawdzie był on przez długi czas przywódca polskiej kontrreformacji, przyczynił się jako prymas do elekcji Zygmunta, a podczas jego wypraw do Szwecji faktycznie pełnił funkcję namiestnika, ale nie należał do ścisłego grona wykonawców jego polityki. Popierał dążenie króla do unii wyznań, ale nie odegrał na tym polu wybitnej roli; był w ogóle

65. M. Dzieduszycki, Piotr Skarga..., dz. cyt., t. 2, s. 362. Strój i fizjonomia Zygmunta III w Skardze są repliką postaci z rysunku w Ubiorach w Polsce, a jego wzorem był portret ze zbiorów Ambrożego Grabowskiego (J. Matejko, Ubiory w Polsce 1200-1795, Kraków 1967, s. 166-167).

66. J. U. Niemcewicz, Spiewy historyczne, dz. cyt., s. 294.

67. A. Naruszewicz, Żywot..., dz. cyt., t. 1, s. 116; por. też H. Schmitt, Rokosz..., dz. cyt., s. 48. Szujski zaś odnotował podobne zarzuty Stadnickiego (Dzieje Polski, dz. cyt., dz. cyt., t. 3, s. 203).

68. Por. J. Krawczyk, Matejko i historia, dz. cyt., s. 97, 101. 
raczej niezdolny do bardziej czynnego działania z powodu wieku (malarz ukazał go jako zgrzybiałego starca). W ostatnim okresie życia, gdy narastał już wewnętrzny konflikt, miał on napominać króla za zamiłowanie do "gier kartowych"69. Dopuścił się też wtedy (bodaj niezamierzonej) jego obrazy w trakcie pierwszego starcia z opozycją na sejmie inkwizycyjnym. Prymas, jak pisał Szujski, "zdziecinniały wiekiem", apelował doń wtedy, aby Polskę cenił wyżej nad Szwecję, gdzie jego ojciec włada tylko nad chłopami ${ }^{70}$. W obrazie nie ma najbliższych współpracowników króla; brak kogoś z najbardziej zaufanych wyższych urzędników, jak podkanclerzy koronny Piotr Tylicki, jego następca Jan Tarnowski (potem prymas), marszałek wielki koronny Zygmunt Myszkowski czy uważany za szarą eminencję dworu podkomorzy koronny Andrzej Bobola, jest znamienny. Nie ma też nikogo spośród najznaczniejszych, popierających dwór senatorów (jak np. bracia Potoccy). Oznacza to, że nie ma "stronnictwa dworskiego", a zatem nie "regaliści" i "program regalistyczny", wokół którego swą interpretację zbudował Krawczyk, są dla Matejki kwestią najważniejszą. Również i ta konstatacja nakazuje interpretować przesłanie obrazu w perspektywie całokształtu problemów epoki i dokonań tytułowego bohatera, a nie tylko związku Kazań sejmowych z kwestią ustrojowego umocnienia monarchii ${ }^{71}$.

\section{Między królem a rokoszem - kanclerz Zamoyski i książę Ostrogski}

W ślad za sugestią, że Skarga Matejki rekomenduje projekt „regalistyczny" idzie teza, iż usiłuje on do niego przekonywać skupione wokół Zamoyskiego "centrum"72. Ta supozycja jest nader dowolna, a samo pojęcie niezbyt tu adekwatne. Kanclerz i hetman w jednej osobie, siedzący na usytuowanym na podwyższeniu tronie, "na poziomie" kaznodziei, jest ukazany jako ktoś nie tyle pomiędzy królem a rokoszem, ile ponad nimi. To bez wątpienia jedyna w obrazie postać, która głęboko rozumie diagnozę Skargi i w pełni podziela jego obawy. O takim miejscu Zamoyskiego pisał sekretarz artysty: „on jeden jako prawy syn ojczyzny nie mając obciążonego sumienia, pojmuje czem

69. W. Koronowicz [Wróblewski], Słowo..., dz. cyt., t. 2, s. 83; por. H. Schmitt, Rokosz..., dz. cyt., s. 48.

70. J. Szujski, Dzieje Polski, dz. cyt., t. 3, s. 158.

71. Jak pisał niedawno Krzysztof Koehler, Kazań sejmowych współcześnie nie zauważono i rokoszanie z nimi nie polemizowali (Boży podżegacz, Warszawa 2012, s. 232).

72. Por. J. Krawczyk, Matejko i historia, dz. cyt., s. 100-101. 
są dla narodu upomnienia Skargi [...] jako polityk wie on, jakie są w kraju niebezpieczeństwa"73. Niemłody już mąż stanu (w rzeczywistości rokoszu już nie dożył) odgrywał w życiu różne, a z perspektywy ustrojowo-ideologicznej sprzeczne role: był promotorem demokracji szlacheckiej, podporą tronu Batorego, ale też twardym, choć nieprzekraczającym granicy buntu krytykiem działań Zygmunta. Ponad to wybija się jednak polityczna mądrość, miłość ojczyzny i troska o dobro wspólne - to wolno uważać za wspólny mianownik jego postępowania i to ma zapewne reprezentować w obrazie.

Trudno przyjąć, że malarz kazał Skardze przekonywać do politycznego programu tego, kogo współcześni i potomni uważali powszechnie za prawdziwego męża stanu, największego w tej epoce (choć bardzo różnie tę ocenę uzasadniali). Historyczny Skarga też zapewne nie widział potrzeby przekonywania kanclerza, skoro widział w nim wręcz zbawcę ojczyzny. W kazaniu na cześć jego zwycięstwa w Mołdawii w 1600 roku zwracał się doń: „wszystkoś rzeczpospolitej darował, wszystkoś miłując ojczyznę hojnie wylał, abyśmy wszyscy nie ginęli. Przeto sława twoja wieczna i pamiątka w błogosławieństwie zostanie [...] miłośnikowi ojczyzny sława wieczna i u Boga odpłata!"74. I takim właśnie pokazał go Matejko: w obrazie jest tym, który z perspektywy politycznej, innej niż prorocza, dana Skardze, widzi i wie to samo ${ }^{75}$. Przyznając mu wyróżnione, należne królowi miejsce, malarz sugerował być może i to, że jego zdolności Polska nie wykorzystała w pełni, że stałoby się tak, gdyby faktycznie zasiadł na tronie - wtedy dzieje potoczyłyby się może inaczej $^{76}$. W jego epoce nie brakło takich ocen; Koronowicz-Wróblewski pisał, że Zamoyski, niwecząc usiłowania elekcji Habsburga, stał się "kierującym wolą i moralną potęgą narodu, duchem oświetlającym jego drogę obecną, prorokiem jego przyszłości, wodzem posłannictwa". Powinien zatem objąć tron i wykorzystać popularność „na zaprowadzenie w ojczyźnie narodowego

73. M. Gorzkowski, Wskazówki..., dz. cyt., s. 11.

74. Cyt. za: M. Dzieduszycki, Piotr Skarga..., dz. cyt., t. 2, s. 289.

75. Zamoyski przewidywał też publicznie przyszłe nieszczęścia: „jako Wisła krwią płynąć będzie, jako Kraków, dom królów naszych w ręce pohańskie przyjdzie" i groził, że tych, którzy doprowadzą ojczyznę do zguby, czeka potępienie wieczne (Joachima Bielskiego dalszy ciag Kroniki polskiej, zawierajacej dzieje od 1587 do 1598 r., wyd. F. M. Sobieszczański, Warszawa 1851, s. 299-300).

76. Gorzkowski pisał, że Zamoyski był „właściwie królem de facto" (Wskazówki..., dz. cyt., s. 11; por. J. Krawczyk, Matejko i historia, dz. cyt., s. 97-100). 
a silnego rządu", by stać się w ten sposób „wieczystym zbawcą Polski od mającej ją zgubić anarchii"77.

Trudno też zgodzić się z orzeczeniem, że wokół Zamoyskiego skupia się jakieś „centrum" czy w ogóle ktokolwiek - artysta nie sugeruje jego więzi z żadną, prócz Skargi, postacią obrazu. Ale wśród ukazanych tam aktorów wydarzeń jest ktoś występujący w przekazach jako jeden z najbliższych jego współpracowników - jest to przywódca rokoszu, Zebrzydowski. Piszący o tych czasach autorzy notują, że cieszył się on dużym zaufaniem hetmana, który powierzył mu nawet wykonanie swego prywatnego testamentu. To przysparzało mu miru wśród szlachty, która skłonna była wierzyć, że podejmując walkę z tronem, wojewoda krakowski realizował jego testament polityczny ${ }^{78}$. W obrazie jednak nic tych postaci nie łączy - Zebrzydowskiemu Matejko przeznaczył miejsce na biegunie zła, nic bowiem nie wskazuje, by zasługi fundatora słynnej Kalwarii dla Kościoła, jego udział w dziełach miłosierdzia i współdziałanie na tym polu ze Skargą miały zmazywać jego winę główną, którą generowała magnacka pycha ${ }^{79}$. Wolno się domyślać, że funkcja przywódcy rokoszu pozwala artyście uznać go za kogoś, kto ignoruje powinności, jakie w życiu publicznym wyznacza chrześcijaństwo. Przesłanki takiej oceny można znaleźć w jego biografii - znamienny jest przykład, który podał Jan Wielewicki, kronikarz jezuicki (część jego Dziennika wydał potem Szujski). Pisał on, że przeciwstawiając w kazaniu "pysznym panom polskim, zrywającym sejmy", przykład Jezusa umywającego nogi apostołom wywołał gniew Zebrzydowskiego, który te słowa wziął za aluzję do swej postawy (było to w 1606 roku) i wniósł na niego skargę do przełożonego domu zakonnego $^{80}$. Z kolei Naruszewicz pisał, że Zebrzydowski "z przyrodzenia warchoł", organizując rokosz liczył na to, że „albo króla z tronu złoży, albo go ku swojej woli złamawszy [...] sam i panem, i państwem rządzić będzie"81. Wodza anarchicznego buntu, który mimo osobistego zaangażowania Skargi

77. Dziejopis dostrzegał zarazem (bez wątpienia trafnie), że nie pozwoliłaby na to arystokracja, której przypisywał całe zło przeszłości (W. Koronowicz [Wróblewski], Słowo..., dz. cyt., t. 2, s. 21-22).

78. Zob. A. Naruszewicz, Żywot..., dz. cyt., t. 1, s. 121; M. Dzieduszycki, Piotr Skarga..., dz. cyt., t. 2, s. 366 .

79. Gorzkowski powtórzył parę razy, że uosabiał on "pychę bez granic" i "magnacką zuchwałość" (Wskazówki..., dz. cyt., s. 8-9).

80. J. Wielewicki, Dziennik spraw domu zakonnego O.O. jezuitów u Św. Barbary w Krakowie od r. 1620 do r. 1629 (włącznie), Kraków 1886, s. 119 (Scriptores Rerum Polonicarum, 10).

81. A. Naruszewicz, Żywot..., dz. cyt., t. 1, s. 121. 
nie dał skłonić się do zgody, Matejko uważał zapewne - pomimo jego gorliwości religijnej - za modelowy przykład lekceważenia chrześcijańskich norm życia społecznego i zatwardziałej pychy ${ }^{82}$.

Postacią "pomiędzy" obozami może zaś być wspomniany książę Ostrogski, jeśli zgodzić się, że właśnie jego przedstawił artysta. Ten ostatni męski reprezentant znakomitego rodu pojawia się na kartach dzieł historycznych bądź jako ten, który waha się między poparciem króla a dołączeniem do rokoszu, bądź jako próbujący między nimi pośredniczyć. Tę postawę przyjął on przy tym dopiero z upływem czasu: najpierw jako kasztelan krakowski, pierwszy świecki senator w państwie, zapowiadał, że wezwie do broni całą szlachtę, by nie wpuścić do Polski Rakuszanki - Konstancji, wnuczki cesarza Ferdynanda I, przybywającej, by poślubić króla po śmierci jego pierwszej żony, a swej siostry. (Przed spełnieniem tej pogróżki powstrzymywał go Zamoyski, ukazując groźbę niemożliwej do opanowania anarchii ${ }^{83}$ ). W małżeństwie tym widziano bowiem - jak pisał apologeta rokoszu - „zmowę z innymi monarchami na zniesienie wolności i wolnej elekcji królów i podejrzewano Zygmunta, że z pomocą obcych sił zbrojnych myśli o zaprowadzeniu samowładnych rządów w Polsce" ${ }^{84}$. Książę Ostrogski, "najmożniejszy może z panów polskich", bywał też wówczas w Lanckoronie u Zebrzydowskiego na poufnych naradach, które poprzedzały otwartą opozycję szlachty. Cytowany autor uznał, że okazał się on jednak „człowiekiem dość chwiejnej wiary", który postępując tak, „jakoby na dwóch chciał siedzieć stołkach", zabezpieczał się na wypadek zwycięstwa każdej ze stron i ostatecznie "zadał najboleśniejszy cios rokoszowi"85. Chodzi niewątpliwie o to, że porzuciwszy lawirowanie, poparł on w końcu króla i był jednym z dowódców jego wojsk w bitwie pod Guzowem.

82. Szujski uważał szerzenie się takiej postawy za negatywny objaw reakcji katolickiej; pisał, że mimo wysiłków Skargi, dominowała „religia, kontentująca się pozorami, nie wnikająca w tajnie sumienia obywatelskiego, religia obiecująca panegiryk i wieczne zbawienie fundatorowi klasztoru, choćby był burzycielem ojczyzny" (J. Szujski, Dzieje Polski, dz. cyt., t. 3, s. 272). Zapewne była to aluzja do postawy Zebrzydowskiego, w każdym razie był on jej najbardziej spektakularnym przykładem.

83. Por. W. Koronowicz [Wróblewski], Słowo..., dz. cyt., t. 2, s. 95.

84. H. Schmitt, Rokosz..., dz. cyt., s. 64, 68.

85. H. Schmitt, Rokosz..., dz. cyt., s. 84, 111, 152. 


\section{Ostrogski i kwestia unifikacji wyznaniowej Rzeczypospolitej}

Postać kasztelana krakowskiego ma istotne znaczenie w perspektywie przywołanej w obrazie kwestii unii religijnej. Zarówno jego dziad Konstanty, słynny wódz i pogromca Moskwy, jak i ojciec, Konstanty Bazyli (Wasyl), byli największymi protektorami prawosławia w państwie polsko-litewskim. Ten drugi dożył czasu, kiedy w Moskwie powstał autokefaliczny patriarchat, na który patriarcha Konstantynopola scedował prawa zwierzchności nad całą Rusią, a więc także nad prawosławną ludnością Rzeczypospolitej. Ostrogski, pojmując powstałe zagrożenie, zaczął zabiegać w Rzymie o unię, ale dzieła tego dokonał bez jego udziału zachęcany przez jezuitów Zygmunt III. Dumny magnat tego nie zaakceptował i zwalczał ustalenia synodu w Brześciu, podsycając konflikt, wywołany przez podział hierarchii i wiernych w tej sprawie ${ }^{86}$. Ukazany na obrazie jego syn porzucił natomiast tradycję rodu i jeszcze przed aktem unii przeszedł na katolicyzm, stał się protektorem jezuitów, a potem miał nawet odbierać prawosławnym ufundowane przez dziada cerkwie.

Istotny motyw wizji dziejów Polski Matejki stanowi apologia jej misji na Wschodzie, zgodna zasadniczo z romantyczną, ale w przeciwieństwie do kręgów lewicowych malarz łączył z tą ideą unię religijną, a nie tylko wspólnotę polityczną. Liczne tego przykłady zawiera jego twórczość, a znamienne jest także materialne wspieranie prześladowanych przez Rosję katolików obrządku greckiego. W tryptyku Królowa Korony Polskiej obok polskich świętych i wodzów poległych w obronie chrześcijaństwa artysta ukazał męczenników z Podlasia, antycypując niejako ich późniejszą o ponad wiek kanonizację. Prześladowania unii były bezpośrednim impulsem do rozpoczęcia malowania Wernyhory, dzieła ukazującego utopijną wizję Ukrainy, która w rezultacie misji dziejowej Polski stała się ziemią zgody i braterstwa Lachów i Rusinów w duchu prawdziwie chrześcijańskim. (Obraz zapowiadał zarazem przyszłe zwycięstwo nad wspólnym wrogiem, "szatańską", prawosławną Rosją). Spektakularnym wyrazem solidarności artysty z katolikami obrządku greckiego były szkice do ikonostasu w cerkwi św. Norberta w Krakowie (obrazy według nich namalowali następnie jego uczniowie). Zaangażowany stosunek do unii religijnej jako fundamentu jedności Rusinów z Polakami stanowi wyrazisty

86. Dzieduszycki pisał, iż urażony kniaź „działał w duchu moskiewskim i trudności mieczem rozciąć przedsięwziął", łącząc z tym wywołanie buntu Kozaków pod wodzą Nalewajki (Piotr Skarga..., dz. cyt., t. 2, s. 107, 121, 127-128). 
motyw widzenia dziejów w późniejszym okresie twórczości Matejki ${ }^{87}$. Ale nie ma też powodu, by sądzić, iż myślał on inaczej w czasie pracy nad Skarga, zwłaszcza że mocno na niego oddziałujący Szujski kreślił wtedy wizję unii wyznaniowej jako „wiekopomnego dzieła Polski, które przetrwało jej upadek i od gwałtownego wytępienia którego grabieżczy carat rozpoczął wojnę na zabój z cywilizacją katolicką" ${ }^{88}$.

Można uznać, że malując Kazanie Skargi, artysta stawiał pomnik najważniejszemu po stronie katolickiej twórcy unii brzeskiej. Wagę działań Skargi na tym polu eksponował Mickiewicz, mówiąc, że uświadamiał on rodakom żywotność "sprawy ziem ruskich" i głosił, że "jedynym sposobem związania ich na zawsze z Rzecząpospolitą było zjednoczyć je z Kościołem"89. Jego biograf pisał zaś, że on pierwszy "na szyzmę z całą przewagą wiary, rozumu i dziejów uderzył", co uznał za "prawdziwą zasługę obywatelską", gdyż wspólne wyznanie stanowiło "główne drzwi dla wpływu moskiewskiego na licznych w Polsce Rusinów"90. Zasługa Skargi nie ograniczała się tylko do sformułowania i nadania najwyższej rangi idei unifikacji religijnej społeczeństwa. Na synodzie brzeskim wspierał posłów króla, którzy go „jako jednego z głównych sprawców unii umyślnie sobie wyprosili"; wkrótce miał też opisać przebieg tych wydarzeń ${ }^{11}$. W obrazie sprawa ta wiąże się więc z głównym bohaterem jako jeden z jego tytułów do chwały, ale w recepcji nie byłoby to oczywiste, gdyby nie postać Hipacego Pocieja. Nikt nie nadawał się lepiej, by wyrazić intencję usytuowania unii wyznań wśród najważniejszych dokonań epoki, niż główny jej promotor ze strony prawosławia. Wraz z Terleckim pertraktował z władzami Rzeczpospolitej i nuncjuszem Malaspiną, podróżował do papieża po akceptację powziętych ustaleń ${ }^{22}$, organizował synod, wreszcie podpisał akt unii. Jako biskup, a potem metropolita zjednoczonej z Kościołem łacińskim wspólnoty, Pociej wyróżniał się postawą zdeterminowanej obrony tego dzieła i stał się jego męczennikiem, gdy ranił go fanatyk, działający

87. Te i inne przykłady zaangażowania Matejki w "sprawę ruską" oraz próbę interpretacji obrazu przedstawiłem w: H. M. Słoczyński, Wernyhora - wieszczba lirnika $i$ wizja malarza, "Biuletyn Historii Sztuki" 47 (1985) nr 3-4, s. 245-256.

88. J. Szujski, Dzieje Polski, dz. cyt., t. 3, s. 172.

89. A. Mickiewicz, Literatura słowiańska, dz. cyt., s. 569.

90. M. Dzieduszycki, Piotr Skarga..., dz. cyt., t. 2, s. 265; powszechnie dostrzegano znaczenie dzieła Skargi O jedności Kościoła; Szujski podkreślał, że torowało ono drogę do unii (Dzieje Polski, dz. cyt., t. 3, s. 171).

91. M. Dzieduszycki, Piotr Skarga..., dz. cyt., t. 2, s. 134-135.

92. Por. M. Dzieduszycki, Piotr Skarga..., dz. cyt., t. 2, s. 105. 
jakoby "z namowy szyzmatyckich starszych". Miał on wtedy wyprosić łaskę dla zamachowca, którego skazano na śmierć, Skarga przywoływał zaś potem jego oświadczenie o gotowości męczeństwa za sprawę jedności religijnej ${ }^{93}$.

Nie może być zatem wątpliwości, że przywołując na obrazie unię wyznań, Matejko ukazał ją jako „wiekopomne dzieło Polski", jak to wiele razy wyrażał później, a zarazem jako dokonanie tytułowego bohatera. W tym kontekście rysuje się znaczenie postaci Ostrogskiego. Pierwszy katolik w najbardziej zasłużonym dla prawosławia rodzie zawdzięcza swe miejsce na płótnie zapewne temu, że mógł służyć jako znakomity przykład akcji nawracania, którą wytrwale i skutecznie prowadził Skarga, dając świadectwo jego zasług w dążeniu do jedności religijnej. Ponadto mógł być też przecież uznany za przykład "nawrócenia" politycznego: był tym, który zrozumiał zgubny wymiar destrukcyjnej formy opozycji forsowanej przez Zebrzydowskiego i jego komilitonów. Na obrazie znalazły się też postacie, które to miejsce zawdzięczają bez wątpienia jedynie związkom z aktywnością stricte religijną Skargi. Usytuowane wśród najważniejszych protagonistów wydarzeń trzy kobiety, które, jak to ujął sekretarz artysty, "z wzniesionem do Boga sercem, modlą się i w pobożności czerpią otuchę"94, poza Anną Jagiellonką nie odegrały istotniejszej roli politycznej. Można to orzec, choć ich identyfikacja jest niepewna (publikacja objaśniająca personalia bohaterów i tu podaje sprzeczne dane). Tekst objaśnienia wymienia obok ostatniej z Jagiellonów "Herburta Mikołaja, wojewody ruskiego żonę" i Zofię Ostrogską, bratanicę księcia Janusza (później żonę Stanisława Lubomirskiego, wojewody krakowskiego). Litografia identyfikuje zaś Agnieszkę, żonę Mikołaja Firleja, wojewody krakowskiego (przed Zebrzydowskim) i Katarzynę Ostrogską (to imię nosiły zarówno siostra, jak i żona Janusza) ${ }^{95}$.

Ten drugi wariant wydaje się dużo bardziej prawdopodobny: nie tylko pokrywa się z danymi późniejszej broszury Gorzkowskiego, ale też oczywisty

93. Por. M. Dzieduszycki, Piotr Skarga..., dz. cyt., t. 2, s. 524, 532. Trudno stwierdzić, czy Matejko miał dane, by uważać Pocieja za ucznia Skargi, jak później uważał Iwan Franko (J. Hryckowian, Iwan Franki poglądy na kwestię unii brzeskiej, w: Unia brzeska, geneza, dzieje i konsekwencje, red. R. Łużny, F. Ziejka, A. Kępiński, Kraków 1994, s. 448).

94. M. Gorzkowski, Wskazówki..., dz. cyt., s. 13.

95. W literaturze identyfikowano też tę postać jako słynną Halszkę z Ostroga, która była m.in. tytułową bohaterką dramatu Szujskiego (zob. np. M. Treter, Matejko: osobowość artysty, twórczość, forma i styl, Lwów-Warszawa 1939, s. 213), a błąd ten powielili też Krawczyk (Matejko i historia, dz. cyt., s. 67) i niżej podpisany (H. M. Słoczyński, Matejko, Wrocław 2000, s. 77). 
jest związek wymienionych tu postaci z innymi bohaterami obrazu, czego nie da się powiedzieć o pierwszej wersji. Trudno dociec, co z treścią dzieła mogłoby łączyć Herburtową (wojewodzina ruska nosiła imię Katarzyna - w objaśnieniu tylko nazwisko). Zupełnie inaczej jest z Agnieszką z Tęczyńskich Firlejową, która była za młodu ulubioną dwórką królowej Anny, pierwszej żony Zygmunta, przyjaźniła się blisko z parą monarszą i towarzyszyła jej w podróży do Szwecji. Jej życie, zwłaszcza po wczesnym owdowieniu, mogło uchodzić za świetny przykład odnowy religijnej epoki, która była owocem głównie działań Towarzystwa Jezusowego. Jako właścicielka wielkiej fortuny, Firlejowa angażowała się w dzieła dobroczynności i chrześcijańskiego miłosierdzia, związane z osobą Skargi, który okresowo pełnił funkcję jej spowiednika i kierownika duchowego ${ }^{96}$. Z podobnego powodu wydaje się, że artysta nie ukazał Zofii Ostrogskiej (za życia kaznodziei króla była ona jeszcze dzieckiem). Trzecia z kobiet to zapewne Katarzyna, siostra Janusza, która podobnie jak on porzuciła wyznanie ojców, przechodząc na katolicyzm. Konwersją potomstwa głównego obrońcy prawosławia Skarga posługiwał się w propagowaniu dzieła unii - pisał o tym fakcie w przedmowie do swego dzieła O jedności Kościoła, które dedykował właśnie księciu Konstantemu ${ }^{97}$. Obecność rodzeństwa Ostrogskich to zatem bez wątpienia kolejny element konstytuujący w obrazie znaczenie unifikacji religijnej w historii Polski.

\section{Rokoszanie wobec dążeń Skargi do unifikacji wyznaniowej}

Sprawa ta ma ścisły związek z rokoszem - uważano, że unia spowodowała "uszczerbek wolności" wyznania greckiego i stawiano żądania jej cofnięcia ${ }^{98}$. Chociaż na czele ruchu stał gorliwy katolik, to jego siłą napędową byli głównie różnowiercy z wyznań reformowanych, postrzegający unię jako element szerszych planów tronu, które uznali za groźne dla wolności kultu, toteż w prawosławiu skłonni byli szukać sojusznika ${ }^{99}$. Ale unifikacji obawiali się też katolicy,

96. Por. K. Lepszy, Firlejowa Agnieszka, w: Polski słownik biograficzny, t. 7 Kraków 1948, s. 17-18; późniejsze działania Firlejowej wiązały się z karmelitami, którym ufundowała klasztor w Czernej; w ścisłym kręgu oddziaływania Skargi pozostały zaś jej córki (M. Dzieduszycki, Piotr Skarga..., dz. cyt., t. 1, s. 374-375, t. 2, s. 541).

97. Por. M. Dzieduszycki, Piotr Skarga..., dz. cyt., t. 1, s. 269; por. M. Dzieduszycki, Piotr Skarga..., dz. cyt., t. 2, s. 124 .

98. Por. M. Dzieduszycki, Piotr Skarga..., dz. cyt., t. 2, s. 385; J. Szujski, Dzieje Polski, dz. cyt., t. 3, s. 208.

99. Dysydenci i prawosławni zawarli wtedy nawet konfederację w obronie swych religii, ale praktycznie nie miała ona znaczenia (J. Szujski, Dzieje Polski, dz. cyt., t. 3, s. 173-175). 
przekonani, że grozi ona absolutum dominium. Szujski, choć ze zrozumieniem pisał o niektórych przyczynach rokoszu, oceniał go bardzo krytycznie, wskazując, że podnoszone wobec władcy zarzuty nie usprawiedliwiały buntu ${ }^{100}$. Odrzucał zwłaszcza stanowczo protesty w sprawie unii, co współgra z jej - przywołaną wyżej - apologią. Podkreślał, że nie było to „dzieło koterii, narzucone narodowi", ale „akt narodowy i popularny", aczkolwiek dokonany za sprawą jezuitów ${ }^{101}$. (Młody historyk tkwił jeszcze po części w tej aurze potępienia, jaką roztaczano od dawna nad zakonem, przypisując mu złowrogi spisek przeciw polskiemu duchowi wolności). Rokosz uważano nieraz za ruch per excellence różnowierczy, co jest pewnym uproszczeniem, ale postulat swobody wyznania i krytyka polityki unifikacji bezsprzecznie należały do istoty ideologii, z której wyrastał. Sam Skarga, odpowiadając na zarzuty dysydentów wobec swego zakonu, podkreślał ich wpływ na rokoszan; twierdził, że to właśnie oni nadali ton zjazdowi sandomierskiemu i pociągnęli za sobą część łatwowiernych katolików. W liście do generała zakonu Claudia Acquavivy pisał zaś, że przeciwnikom królewskim "przewodzą heretycy" ${ }^{102}$. W jego pismach jako naczelne trapiące Polskę zło i przyczyna ogółu obecnych i przyszłych nieszczęść rysuje się niezgoda wewnętrzna, której źródłem i istotą są podziały religijne oraz destrukcyjna niejako z natury aktywność różnowierców w sferze publicznej ${ }^{103}$. I to właśnie było clou jego diagnozy, a program "regalistyczny" jako całość miał tu znaczenie drugoplanowe, choć Skarga niewątpliwie wspierał go jako istotny środek osiągnięcia moralno-religijnej jedności.

Jako najwybitniejszy szermierz polityki unifikacji, działający z wielką energią i determinacją (choć nie zalecający przymusu nawracania), Skarga spotykał się z wrogością opozycji. W miarę umacniania się Kościoła różnowiercy odczuwali coraz większą presję, a świadomość utraty znaczenia ich obozu, jeszcze do niedawna tak potężnego, wzmagała obawy o przyszłość

100. Zob. J. Szujski, Dzieje Polski, dz. cyt., t. 3, s. 197; zarazem autor bardzo krytycznie oceniał politykę zagraniczną dworu oraz wpływy jezuitów.

101. J. Szujski, Dzieje Polski, dz. cyt., t. 3, s. 170-171. Wydaje się, że ta konstatacja "popularności" unii, pomimo wiedzy o wrogim stanowisku rokoszu, wynikała zarówno z przekonania, że nie uczestniczyła w nim szlachta całej Polski (historyk podkreślał, że był to ruch "lokalny" i nie objął Mazowsza ani Rusi, a na Litwie tylko stronników Radziwiłła - J. Szujski, Dzieje Polski, dz. cyt., t. 3, s. 198), jak i z oceny, że nie wszyscy jego uczestnicy popierali żądanie likwidacji unii.

102. M. Dzieduszycki, Piotr Skarga..., dz. cyt., t. 2, s. 460, 468-469, 450. Naruszewicz pisał zaś, że różnowiercy uznali wzrost niezadowolenia z powodu polityki dworu za "sposobną porę" do „wynurzenia zemsty" (Żywot..., dz. cyt., t. 1, s. 123).

103. Współcześnie podkreśla to dobitnie Koehler (Boży podżegacz, dz. cyt., s. 212-213). 
wolności wyznania. Biograf Skargi, wskazując ogrom jego zasług na tym polu, pisał, że szala przechyliła się już za czasów Batorego, a za jego następcy gmach reformacji, „całkiem spróchniały, pochylony [...] runął ostatecznie o ziemię"104. Perspektywa taka rysowała się już wyraźnie na początku stulecia i stąd opozycję w tak dużej liczbie stanowili niekatolicy. Warto dodać, że rola dysydentów w ruchu rokoszowym mogła umacniać niechęć Matejki, który już od lat szkolnych deklarował postawę ortodoksyjnego wyznawcy ${ }^{105}$.

\section{Sprawa interwencji w Moskwie - przeciwnicy i protagoniści}

Jak już wskazałem, dziedziczona po romantyzmie tradycja odnoszenia dziejowej misji Polski do państwa carów łączyła szanse unicestwienia ich okrutnej tyranii i zaszczepienia polskich instytucji wolnościowych również z czasami Zygmunta III, kiedy jego syna wybrano na tron w Moskwie, a polska załoga stała na Kremlu. Te możliwości tworzyła sprawa fałszywego Dymitra, zapoczątkowana akurat w czasie narastania opozycji, które poprzedziło rokosz. Jego twórcy byli przeciwni wspieraniu roszczeń pretendenta, w przekonaniu, że tę prywatną wyprawę paru magnatów aprobował skrycie tron, a inspirowali jezuici. Odnowienia się konfliktu z Rosją obawiał się zresztą ogół klasy panującej, zwłaszcza że w Inflantach trwała wojna ze Szwecją, a nie ustawało zagrożenie ze strony Turcji (Zamoyski u schyłku swych dni ostrzegał przed groźbą powstania kolejnego frontu). W ogóle polityka pokojowa była wtedy zasadniczym postulatem szlachty, chcącej korzystać z socjalnych i politycznych przywilejów zdobytych w ostatnim wieku i z dostatku, który przyniosła świetna koniunktura na produkty rolne, gdy tymczasem żądano od niej ponoszenia kosztów wojen, tak ze Szwecją, jak w obronie rubieży południowo-wschodnich. Szujski podkreślał, że absolutna dominacja tej warstwy w układzie społecznym i jej ogromne uprawnienia polityczne generowały naturalną koleją rzeczy niechęć do wszelkich ofiar, że stopniowo popadała ona w egoistyczne samozadowolenie, ignorując konieczność ciągłego wysiłku na rzecz obrony granic ${ }^{106}$. Wskazywał też jej obawy co do tego, że polityka

104. M. Dzieduszycki, Piotr Skarga..., dz. cyt., t. 1, s. 397.

105. W jednym z listów 20-letni uczeń wyrażał przeświadczenie, że „bez religii, i do tego katolickiej, nic nie można zrobić, co by się nawet miernem zwać mogło" (Z listów Jana Matejki 1856-1863, Kraków 1895, s. 19).

106. Myśl tę Szujski rozwinął nieco później, ale już w Dziejach pisał, że za Zygmunta III „przestał naród pełnemi piersiami oddychać i rozwijać się", zaś szlachtę opanowały domatorstwo i lenistwo (Dzieje Polski, dz. cyt., t. 3, s. 271). 
aktywna, uprzedzająca zagrożenia, groziła utratą osiągniętej pozycji, gdyż wymagała licznej stałej armii, którą zwycięski król łatwo mógłby wykorzystać jako narzędzie do zaprowadzenia absolutum dominium.

W kontekście wskazanych już wątków Skargi rysuje się istotne znaczenie przedstawienia wojewody sandomierskiego Jerzego Mniszcha, inicjatora wyprawy fałszywego Dymitra po czapkę Monomacha i ojca carowej Maryny oraz Jana Piotra Sapiehy, najsłynniejszego wodza prywatnych oddziałów polskich, walczących w państwie carów. To chyba oczywiste, że skoro ich miejsce na kartach historii wynika wyłącznie z prominentnego udziału w "dymitriadzie", to właśnie o jego podkreślenie chodziło artyście. Tym bardziej, że nie sposób sobie wyobrazić całościowego obrazu epoki bez tego wydarzenia Karol Sienkiewicz pisał, że „wśród natłoku wypadków, zdarzonych za tego króla [Zygmunta III], te zaiste, co zaszły w Moskwie, górują nad innymi ważnością i nauką"107. Ale wpisanie tych postaci w strukturę znaczeniową dzieła nie jest proste, skoro brak tam bliższych wskazówek, a próby ustalenia na podstawie innych przesłanek, która spośród ocen polskiej interwencji w Rosji była Matejce bliska, nie prowadzą do jednoznacznych rezultatów.

Odczytując dzieło malarstwa historycznego, tworzące kompleks znaków ikonicznych, które z natury rzeczy nie są jednoznacznym medium przekazu treści, łatwo przypisać twórcy intencje mu obce. Dużej ostrożności wymaga łączenie potencjalnych elementów znaczących obrazu z przypuszczalną wiedzą historyczną artysty: gdy nie ma pewności, że znał on określone fakty, powiększa się ten obszar interpretacji, który może być tylko kwestią domniemań. Jeśli jednak badaczowi uda się ułożyć rozszyfrowane elementy w spójną całość, to prawdopodobieństwo trafności takiego rezultatu lektury merytorycznej zawartości i ogólnego przesłania dzieła wydaje się bardzo duże. Świadomy tych trudności, z pewną rezerwą przedstawiam próbę identyfikacji niewyraźnej grupy postaci, która wyłania się z głębokiego tła obrazu, zza zarysu konfesji św. Stanisława, jak też odczytanie jej funkcji. W każdym razie wiedza o stanowiących kanwę dzieła wydarzeniach, prawdopodobnie lub wręcz na pewno znana Matejce, pozwala poddać weryfikacji interpretację, którą przedstawił Krawczyk. Uznawszy tę grupę za Bractwo Męki Pańskiej odprawiające pokutę w intencji obrad sejmu, orzekł on, że przedstawiony epizod współtworzy przesłanie dzieła, oparte na logice winy i kary, ekspiacji

107. K. Sienkiewicz, Polska i Moskwa za Zygmunta III, w: K. Sienkiewicz, Skarbiec historii polskiej, t. 1, Paryż 1839, s. 289. 
i Bożego zmiłowania, a zatem powtarzające motyw słynnej średniowiecznej legendy męczennika-patrona Polski ${ }^{108}$. Identyfikację tę wydaje się przy tym wspierać fakt niezauważony przez autora: rysunek Matejki w Ubiorach w Polsce, przedstawiający członków bractwa.

Jednakże jeśli te słabo widoczne postacie niosą krzyż procesyjny (a tak istotnie się wydaje) i są ubrane w pokutne wory, to może to być raczej Arcybractwo Miłosierdzia, ściśle związane z ważnymi postaciami obrazu ${ }^{109}$. Założył je Skarga, a pośród aktywnych „braci" byli król oraz Zebrzydowski, co we Wskazówkach do obrazu przywołał sekretarz artysty ${ }^{110}$. Ukazanie tego właśnie bractwa może odnosić się do aktywności przywódcy rokoszu w jego ramach, a przez to wskazywać na kolizję jego pobożności z niegodną chrześcijanina postawą w sprawach publicznych. Ale bardziej frapująca jest perspektywa, że malarz mógł przywołać niezwykle barwny, a przy tym ważny dla genezy "dymitriady" epizod. Gdy oto rzekomy Dymitr szukał w Polsce poparcia wpływowych czynników, Zebrzydowski był jego protektorem i ułatwił mu kontakt z jezuitami. Cytowany już kronikarz, który przekazał wiele cennych informacji o tej sprawie, napisał, że w Wielką Sobotę 1604 roku ci dwaj zbierali najpierw datki w kapturach arcybractwa, by móc przejść potem incognito do domu zakonnego przy kościele św. Barbary, gdzie Samozwaniec odbył spowiedź przed jezuitą o. Kasprem Sawickim i złożył deklarację przynależności do Kościoła katolickiego ${ }^{111}$.

Ten epizod Matejko musiał znać z dzieła Dzieduszyckiego ${ }^{112}$, ale ten autor, usiłując wyraźnie minimalizować wsparcie zakonu dla łże-Dymitra, nie przedstawił tej kwestii szerzej. Jednak artysta zaintrygowany jego sensacyjnością mógł zapewne dotrzeć do oryginału Dziennika Wielewickiego, który znajdował się w zbiorach Józefa Muczkowskiego, wówczas jeszcze niewydany"13. Mógł to uczynić przy pomocy Szujskiego, który ewidentnie nie znał tego

108. Zob. J. Krawczyk, Matejko i historia, dz. cyt., s. 111-118.

109. Cytowany przez Krawczyka Józef Muczkowski pisał, że właśnie Arcybractwo Miłosierdzia zaprowadziło jako pierwsze „używanie podczas procesji pokutnych worów" i w tych strojach wiele „najznakomitszych osób", także sam król, odprawiało nabożeństwa pokutne (Bractwa jezuickie i akademie w Krakowie, Kraków 1845, s. 44, 81-83).

110. Zob. M. Gorzkowski, Wskazówki..., dz. cyt., s. 9; M. Dzieduszycki, Piotr Skarga..., dz. cyt., t. 1, s. 382-383.

111. Zob. J. Wielewicki, Dziennik spraw domu zakonnego..., dz. cyt., s. 57-58.

112. M. Dzieduszycki, Piotr Skarga..., dz. cyt., t. 2, s. 48.

113. Matejko miał kiedyś bliski kontakt z nieżyjącym już wówczas profesorem bibliografii, dyrektorem biblioteki Akademii Krakowskiej i znanym bibliofilem; 
źródła, pisząc Dzieje Polski, a niebawem oprze się na nim w rozprawie Maryna Mniszchówna i obaj Samozwańce, by później wydać je drukiem¹4. Zapiski Dziennika tworzą ciąg poszlak, który wskazuje, że relacje Zebrzydowskiego z "Dymitrem" mogą kryć tajemnicę najważniejszych wydarzeń tamtego czasu. Zestawiwszy je, Szujski dojdzie wkrótce do przekonania, że magnaci przewodzący wyprawie na Moskwę porozumiewali się z opozycją antykrólewską, a ta czekała z ogłoszeniem rokoszu na sukces Samozwańca. Uznał też, że śmierć uzurpatora na Kremlu przeszkodziła rozpoczęciu przezeń wojny z Polską, co miało być skorelowane z proklamacją przez Zebrzydowskiego bezkrólewia, po czym tron w Warszawie miał objąć car Dymitr ${ }^{115}$. Odczytania epizodu z Arcybractwem Miłosierdzia w duchu tych ocen przedstawiam jedynie jako potencjalny element interpretacji obrazu. Poprzez te refleksje chciałbym zaś uświadomić przede wszystkim to, jak subtelnych i głęboko zakamuflowanych treści można się spodziewać w kompozycjach Matejki.

Przedstawiony przez artystę Mniszech, którego zaangażowanie odegrało tak ogromną rolę w podjęciu wyprawy na Moskwę, miał w historiografii opinię najgorszą z możliwych. Pełnił on niechlubną funkcję stręczyciela kobiet do łoża Zygmunta Augusta u schyłku jego życia, był też oskarżany o udział w gorszących scenach towarzyszących śmierci króla i grabież jego kosztowności. Uznania nie przyniosła mu też bynajmniej pierwszorzędna rola w rozpoczęciu „dymitriady"; uważano, że motywami jego działań były jedynie chciwość i ambicja. Szujski cytował później ocenę, jaką wypowiedział o nim uznawany powszechnie za wzór patrioty hetman Stanisław Żółkiewski:

Muczkowski umożliwił mu korzystanie ze zbiorów biblioteki, za co w rewanżu otrzymał obraz Stańczyk udający ból zębów (S. Serafińska, Jan Matejko..., dz. cyt., s. 39, 41, 51). Dziennik był wtedy w posiadaniu jego syna Stefana, potem wiceprezydenta Krakowa, a choć nie wiadomo, czy Matejko miał z nim bezpośrednie relacje, to poświadczona jest jego współpraca z Leonardem Serafińskim, szwagrem artysty, osobą bardzo mu bliską (S. Serafińska, Jan Matejko..., dz. cyt., s. 167; wydawcy tych wspomnień pomylili Stefana z jego ojcem, zob. s. 600).

114. J. Szujski, Maryna Mniszchówna i obaj Samozwańce, w: J. Szujski, Dzieła, seria 2, t. 5, Kraków 1885, s. 232 (pierwodruk w 1867 roku). O tym, że Szujski, pisząc Dzieje, nie znał danych z Dziennika, świadczy to, że wskazał inną drogę dotarcia „Dymitra" do jezuitów (Dzieje Polski, dz. cyt., t. 3, s. 194) i nie odnotował jego związku z przywódcą rokoszu. Za tym, że to Matejko, pracując nad Skarga, mógł zwrócić uwagę Szujskiego na to źródło, przemawia też to, że nie znając dostatecznie łaciny, artysta musiał powierzyć komuś jego odczytanie.

115. Zob. J. Szujski, Maryna Mniszchówna..., dz. cyt., s. 247-248, 251-252, 255, 258. Tezy te poparł później Walerian Kalinka (O książce prof. M. Bobrzyńskiego Dzieje Polski w zarysie, Kraków 1879, s. 50-53). 
otóż zięć cara był dlań przykładem, "jak częstokroć mali, podli, nikczemni ludzie mogą siła złego narobić"116.

Wobec wielu pytań stawia zaś ukazanie na obrazie Sapiehy, wybitnego aktora w kolejnym akcie dramatu, gdy na tronie carskim zasiadł Wasyl Szujski, promotor spisku, który pozwolił usunąć uzurpatora. Pojawili się wtedy nowi Samozwańcy, a przy jednym z nich - ocalałym jakoby z zamachu Dymitrze I - gromadziły się znaczne, głównie polskie oddziały. Żołnierzy łudziła nadzieja nadzwyczajnych gratyfikacji i łupów, tym bardziej, że Rzeczpospolita była wtedy w stanie zatrudnić tylko nielicznych, ponadto notorycznie zalegała z żołdem (niepłatne wojsko Chodkiewicza właśnie zawiązało konfederację i porzuciło służbę w Inflantach ${ }^{117}$ ), a po klęsce rokoszu nie byli oni także potrzebni do rozgrywek wewnętrznych. Najsilniejszym oddziałem w służbie pretendenta dowodził właśnie Sapieha, który jeszcze niedawno walczył po stronie króla pod Guzowem. Armia Samozwańca blokowała stolicę i walczyła z wojskami Wasyla IV, który miał problem z legitymizacją swej władzy, zagrożonej także przez bunty chłopskie. Przeważnie odnosiła sukcesy, choć jej możliwości militarne osłabiały ciągłe spory między Sapiehą a „hetmanem" całości, księciem Romanem Rożyńskim ${ }^{118}$. Gdy wreszcie car uwolnił uwięzionych po zamachu Polaków ze świty Dymitra, w tym carową-wdowę Marynę, ta nie potrafiąc pogodzić się z utratą perspektyw panowania, stanęła u boku pretendenta, w którym „rozpoznała" ocalałego rzekomo męża.

\section{Anarchia a interwencja w Moskwie - Polacy przeciw Polakom}

Nowa sytuacja powstała po przystąpieniu do wojny Rzeczpospolitej. Realizacja planów tronu oznaczałaby dla walczących po stronie Samozwańca żołnierzy utratę ogromnych korzyści, na które liczyli po zdobyciu Moskwy. Ich posłowie wysłani do oblegającego Smoleńsk króla grozili, że wypowiedzą posłuszeństwo ojczyźnie, po ale długich targach udało się skłonić Rożyńskiego do odstąpienia od powszechnie pogardzanego łże-Dymitra. Ten obawiając

116. J. Szujski, Maryna Mniszchówna..., dz. cyt., s. 234.

117. Por. A. Naruszewicz, Żywot..., dz. cyt., t. 1, s. 123-124, 134-135. Miraż bogactw państwa carów stał się kolejną przyczyną kłopotów Chodkiewicza w Inflantach, ponieważ liczni żołnierze „zhydziwszy trudy i niebezpieczeństwa w tej prowincji, rzucali oczy na zyskowną w Moskwie fałszywych Dymitrów rewolucję" (A. Naruszewicz, Żywot..., dz. cyt., t. 1, s. 169).

118. Szujski pisał, że obaj dowódcy przeszkadzali sobie nawzajem (Dzieje Polski, dz. cyt., t. 3, s. 226); podobnie A. Naruszewicz, Żywot..., dz. cyt., t. 1, s. 208, 212, 226. 
się o życie, uciekł do Kaługi, a za nim ruszyła Maryna i, jak to ujął Szujski, "przekabacony" przez nią Sapieha z większością najemników. Gdy zwycięstwo pod Kłuszynem otworzyło Żółkiewskiemu drogę do Moskwy, gdzie bojarzy obalili już Wasyla IV i gotowi byli powołać na tron królewicza Władysława Wazę, pojawiła się tam również para pretendentów z armią starosty uświackiego. „Dumna Maryna - pisał Szujski - stanęła jako współzawodniczka syna królewskiego, otoczona hufcami, które królowi Zygmuntowi służyć były powinny"19. Pokrótce nastąpił szczególnie spektakularny epizod tej historii, znamienny nie tylko w kontekście ukazania Sapiehy przez Matejkę: pod murami stolicy imperium carów stanęły dwie armie polskie gotowe do walki ze sobą. Do starcia ostatecznie nie doszło, starosta uświacki ustąpił i porzucił łże-Dymitra, co usunęło ważną trudność na drodze do realizacji planów hetmana. "Gdyby Zygmunt grubych nie popełnił błędów, dynastia Wazów byłaby osiadła na tronie moskiewskim" - oceniał tę sytuację Szujski ${ }^{120}$. Ale rola Sapiehy w tych wydarzeniach jeszcze nie dobiegła końca; być może o czym historyk napisze w późniejszej rozprawie - usiłował on potem zdobyć dla siebie czapkę Monomacha, a część bojarów podobno była skłonna mu ją ofiarować ${ }^{121}$.

Bez wątpienia szczególnie w świetle tego aspektu wydarzeń - rozczłonkowania sił polskich opowiadających się po przeciwnych stronach i służących sprzecznym interesom ${ }^{122}$ - całość działań wobec kryzysu w Moskwie jawi się jako objawiająca się na zewnątrz postać anarchii. Można więc było wiązać z tą sytuacją utraconą okazję do podjęcia ważnych rozstrzygnięć w odwiecznym sporze Polski z północno-wschodnim sąsiadem. Często oceniano, że powstała wówczas możliwość trwałego usunięcia elementu barbarzyńskiej zaborczości w jego polityce, która w następnym stuleciu miała doprowadzić do pozbawienia suwerenności, a potem unicestwienia Rzeczypospolitej. Taką

119. J. Szujski, Dzieje Polski, dz. cyt., t. 3, s. 227-228.

120. J. Szujski, Dzieje Polski, dz. cyt., t. 3, s. 229.

121. Por. J. Szujski, Maryna Mniszchówna..., dz. cyt., s. 271; Sapieha zmarł w Moskwie w 1611 roku.

122. Z drugiej strony osłabiająca Wasyla IV aktywność militarna Samozwańca była w pewnym okresie królowi na rękę, stąd niektórzy historycy sądzili później, że Sapieha działał w porozumieniu z nim (A. Hirschberg, Maryna Mniszchówna, Lwów 1927, s. 152-153; J. Maciszewski, Polska a Moskwa 16o3-1618. Opinie i stanowiska szlachty polskiej, Warszawa 1968, s. 192). Inaczej uważa autor biografii Lwa Sapiehy, który przytacza dowody działań bohatera, aby odwieść krewnego od popierania łże-Dymitra (A. Czwołek, Piórem i buława. Działalność polityczna Lwa Sapiehy, kanclerza litewskiego, wojewody wileńskiego, Toruń 2012, s. 245, 259-260, 270). 
zmianę miałaby przynieść penetracja polskiego "ducha wolności" w państwie carów, bądź też doprowadzenie do jego otwarcia na infiltrację szeroko pojętej cywilizacji Zachodu. Inni zaś, nie wdając się w dywagacje na temat szans zapoczątkowania gruntownego przeobrażenia despotycznego systemu, a dostrzegając możliwość zajęcia przez Wazów tronu carów, wiązali z tym perspektywę mniej lub bardziej trwałej neutralizacji odwiecznego wroga.

\section{Utracona szansa zdobycia i przeobrażenia Rosji w literaturze historycznej}

Niemcewicz oceniał politykę Zygmunta III wobec Moskwy (jak zresztą całe jego panowanie) jako pasmo błędów: nieudolny władca nie umiał korzystać „z najszczęśliwszych zdarzeń" i nie wykorzystał możliwości "nabycia mocarstwa ogromnego". Konstatując utratę tej historycznej szansy, autor pisał, że „opuszczone dobrowolnie korzyści równy żal może wzbudzają, jak klęski samem zdarzone nieszczęściem"123. Natomiast Joachim Lelewel, który uznał, że zwycięstwa Batorego przyniosły możliwość "zupełnej caryzmu moskiewskiego zagłady" (to rozstrzygnięcie mieli powstrzymać jezuici), łączył ponowną taką "sposobność" z wydarzeniami z początku XVII wieku. Jak wolno sądzić z jego lakonicznych i pozbawionych wyraźnej konkluzji uwag, tak się nie stało, gdyż Zygmunt, dążący do zawarcia unii religijnej, chciał sam zasiąść na tronie carów i nie godził się, by rządy w Moskwie objął jego syn, wybrany przez bojarów ${ }^{124}$. Dziejopis-demokrata, który wierzył w oddziaływanie polskiego "ducha gminowładztwa" na Rosję, potępiał zaś działania kontrreformacyjnego Kościoła i łączenie kwestii wyznaniowych z polityką, zachował rezerwę w łączeniu tego posłannictwa wolności z wielką smutą. W świetle jego ideologii dążenie do unii prawosławia i katolicyzmu musiało uchodzić za czynnik, który nie sprzyjał tej misji. Ponadto trudno było godzić interwencję w Moskwie z romantycznym dogmatem o bezinteresownej, unikającej podbojów polityce Polski, toteż dziejopisowie tej epoki, jak Jędrzej Moraczewski czy Henryk Schmitt, nie dostrzegali w niej ekspansji ideałów demokracji, ale raczej dzieło przeciwnych im żywiołów ${ }^{125}$.

123. J. U. Niemcewicz, Śpiewy historyczne, dz. cyt., s. 328, 320; por. także s. 325.

124. Por. J. Lelewel, Wykłady kursowe z historii powszechnej w Uniwersytecie Wileńskim 1822-1824, w: J. Lelewel, Dzieła, t. 3, opr. M. H. Serejski, Warszawa 1959, s. 501-502.

125. Zob. J. Moraczewski, Dzieje Rzeczypospolitej Polskiej, t. 7, Poznań 1865, s. 75-76; H. Schmitt, Dzieje narodu polskiego od najdawniejszych do najnowszych czasów, t. 1, Lwów 1863, s. 601, 612. 
Istotę carskiej tyranii Lelewel ukazywał w postaci metafory jaskini, mającej zarazem wyrażać sens polskiej misji wolności wobec Rosji. Władza despoty trwa tam tylko dzięki panowaniu ciemności: trzyma on w ryzach swych poddanych za pomocą knuta, gdyż ci nie widzą, że jest sam - to zapewnia ich bierność i posłuszeństwo. Pochodnia wniesiona do owej jaskini mroku i niewoli przez przybysza z zewnątrz ujawnia prawdę, daje więzionym poczucie mocy, które pozwala obalić tyrana. Dziejopis-demokrata uznał dalej za rzecz niepojętą, że ilekroć Polacy „zbliżali się ze światłem", by rozproszyć ciemności panujące "w jaskini rosyjskiej, to przez jakieś niepojęte zrządzenie za każdym razem zgasła ich pochodnia"126. Pomijając w tym miejscu pytanie o to, które podejmowane przez Polskę w przeszłości działania można tak opisać, trzeba zauważyć, że rzekoma niezrozumiałość braku reakcji na nie wyraża naiwność obrazu świata, który stał u podstaw przytoczonej metafory. Wolność (tu utożsamiana z "gminowładztwem" szlachty) jest wedle Lelewela zawsze najwyższą wartością dla ogółu, inne zaś są drugorzędne bądź przez nią warunkowane. Ten dogmat nie pozwalał dostrzec poparcia społeczeństwa dla caratu i zakorzenienia samodzierżawia w tradycji rosyjskiej. Nie tu ma miejsca ani potrzeby opisywania meandrów ideologicznych dziejopisa i wizjonera "gminowładztwa", związanych z takim wyobrażeniem polskiej misji wolności na Wschodzie; trzeba zaś wskazać, że miał on niemały kłopot z przekonującym, konkretnym jej usytuowaniem w dziejowych realiach relacji polsko-rosyjskich.

Faktem, jaki mógł przywołać bez kolizji z motywami działających w przeszłości podmiotów, było wspieranie przez część szlachty projektu elekcji Iwana Groźnego na tron w Krakowie. Łączono z tym także nadzieje na przemianę cywilizacyjną Moskwy, podobną do tej, jaka poprzez unię z Polską dokonała się wcześniej na Litwie (chociaż decydowały raczej rachuby na trwalsze ułożenie pokojowych relacji). W głośnym projekcie odezwy sejmowej do Rosjan, pisanym po wybuchu powstania listopadowego, Lelewel akcentował rzekomo idealistyczne przesłanki tych dążeń; pisał, że obranie cara królem planowano „nie w innym, jak wiadomo, celu, tylko aby przez to otworzyć bojarom moskiewskim sposobność pozyskania tych wolności, jakimi się podówczas szlachta polska i litewska cieszyła"127. Drugim przykładem miały być zaś działania Polaków w pierwszej połowie XVII wieku.

126. J. Lelewel, Polska, dzieje i rzeczy jej, t. 20, Poznań 1864, s. 319-320.

127. J. Lelewel, Polska..., dz. cyt., s. $64-65$. 
Uczony, choć nie omieszkał zapewniać, że Rzeczpospolita, przeciwnie niż carowie, "nigdy nie myślała o zaborach" ani nie próbowała pozbawiać swobód $\operatorname{Rosjan}^{128}$, był bez wątpienia świadom polskiej roli w "dymitriadach", które przyniosły przelew krwi ludności cywilnej, upokorzenia i wszelkie okropności brutalnej wojny. Toteż z misją wolności nie próbował łączyć wyboru królewicza Władysława na tron carów, nie chcąc zapewne budzić skojarzeń z tymi traumatycznymi faktami.

Powoływał się zaś na oferty mogące połączyć oba narody „w unią i spólność", przedłożone w Moskwie przez „posłów polskich, Sapiehów”. Używał liczby mnogiej, choć konkretnie odniósł się tylko do jednego, i to mniej znanego poselstwa (pomijając wcześniejsze z nich), z którym w 1600 roku kanclerz wielki litewski Lew Sapieha, jeden z wybitniejszych polskich mężów stanu tej epoki, przybył na dwór cara Borysa Godunowa. Zajął się zaś innym, z 1635 roku, na czele którego stał syn Lwa, Kazimierz Leon. Lelewel zapewniał „Braci Rosjan", iż przyjęcie przedłożonej wtedy oferty, która przewidywała ścisłe współdziałanie (m.in. trwałe przymierze polityczne i mieszane polsko-rosyjskie małżeństwa w obrębie elit), zapewniłoby im "swobody konstytucyjne na sposób Polaków", ale nie dopuścił do tego "despotyzm carów"129. Z podobną propozycją unii przybyło jednakże już to pierwsze poselstwo, może więc dziwić, że dziejopis nie odwołał się do niego ${ }^{130}$. Tym bardziej, że jeśli kiedykolwiek była szansa recepcji jakichś elementów modelu ustrojowego Polski przez Rosję, to tylko w sytuacji potężnego wstrząsu i głębokiego kryzysu, a taka powstała w rezultacie panowania Iwana Groźnego. Doświadczenia tego czasu mogły skłaniać bojarów do zmian, które zabezpieczałyby przed powtórzeniem się takich ekscesów władcy w przyszłości. (Szujski pisał

128. J. Lelewel, Polska..., dz. cyt., s. 64-65.

129. J. Lelewel, Polska..., dz. cyt., s. 65-66. Relację Kazimierza Leona Sapiehy z poselstwa, zawierającą m.in. treść tych postulatów i odpowiedzi cara, zob. w: K. Kognowicki, Życie Kazimierza Leona Sapiehy, w: K. Kognowicki, Życia Sapiehów i listy od monarchów, książąt i innych panujacych do tychże pisane, t. 3, Warszawa 1792, s. $40-43$.

130. Badacz tej epoki pisał ostatnio, że ten „projekt unii z Moskwą w pewnym stopniu stanowił recepcję rozwiązań zaproponowanych w akcie unii lubelskiej" (A. Czwołek, Piórem i buława..., dz. cyt., s. 141). Autor nie przecenia wagi tych planów (pisze, że „rzeczywistym celem" poselstwa z 1600 roku było zawarcie rozejmu) oraz podkreśla, że ówczesnym politykom polskim trudno było dostrzec to, co widać z perspektywy czasu, to znaczy, że „pogodzenie dwóch odrębnych organizmów państwowych, mających osobny ustrój, wyznanie oraz historię, stanowiło zadanie nie do wykonania" (Piórem i buława..., dz. cyt., s. 156-157). O braku szans zawarcia takiej unii pisał też Maciszewski (Polska a Moskwa..., dz. cyt., s. 44). 
później, że był to właściwy moment na „zaborcze wystąpienie" Rzeczypospolitej, które „byłoby raz na zawsze zniszczyło potwór caratu" i doprowadziło do przesunięcia granic aż po Wołgę ${ }^{131}$ ). Żadne trwalsze zbliżenie nie było zaś bez wątpienia możliwe po tym, jak brutalna interwencja polska wykopała przepaść pomiędzy obu narodami. Lelewel ewidentnie tak nie sądził, ale pewnie był świadom, że Rosjanom nie należy zalecać czegoś, co musiało kojarzyć się z doświadczeniem wielkiej smuty. Być może więc dlatego wolał szukać przykładów, które miały dowodzić owej polskiej misji wolności, w bardziej oddalonych w czasie.

Takich obiekcji nie miał zaś Koronowicz-Wróblewski, który przedstawił obszernie i dobitnie sprawę porażki polskiej misji wobec Rosji i nie wahał się łączyć jej z "dymitriadą". Dowodził, że ogromną szansę jej sukcesu poprzedził triumf „zasady republikańskiej" oraz czas rozkwitu kultury polskiej i terytorialnego rozrostu państwa, mające wręcz znamiona cudu. Bóg, który dał te "bogactwa, chciał najpierwej, abyśmy ich użyli na ucywilizowanie Moskwy, na rozbicie jej więzów, na przywrócenie jej znamion i zacności ludu słowiańskiego" - głosił132. Pierwszą próbą działania na tej niwie był plan elekcji Iwana Groźnego, a potem jego syna Fiodora, na tron w Krakowie, z czym łączyła się nie tylko nadzieja pokoju od strony Rosji, lecz także "daleko od tej powabniejsza przyłączenia tego państwa". W tym celu potrzebna była polityka, która wcześniej pozwoliła na akcesję Litwy: „orężem zdobywczym była tu ułuda wolności". Dziejopis uważał, że unia, a w konsekwencji zupełna zmiana oblicza Rosji, była zupełnie realna: wpływ instytucji polskich na bojarstwo spowodowałby przekształcenie go w taką jak w Polsce wolną szlachtę, a to uniemożliwiłoby powrót carskiej tyranii ${ }^{133}$. Twierdził, że spełnienie "powołania narodowego, ucywilizowania północnej Słowiańszczyzny, uzacnienia jej klejnotem wolności polskiej" było możliwe, gdyż "nieubłagana nienawiść między dwoma narodami jeszcze się była natenczas nie wyrobiła"134. Ponadto autor akcentował wspólne pochodzenie obu narodów, pisał o "bratnim ludzie słowiańskim i dwóch narodach jednoplemiennych". Te sformułowania były znamienne, bowiem gdy Moskwa, dążąc do dalszego rozszerzenia imperium i zdobycia Konstantynopola, zmierzała pod sztandarem panslawizmu do rozbicia Turcji, a także głosiła tezę, że "łacińska" Polska zdradziła

131. J. Szujski, Maryna Mniszchówna..., dz. cyt. s. 223.

132. W. Koronowicz [Wróblewski], Słowo..., dz. cyt., t. 1, s. 351-353.

133. Zob. W. Koronowicz [Wróblewski], Słowo..., dz. cyt., t. 1, s. 356-357.

134. W. Koronowicz [Wróblewski], Słowo..., dz. cyt., t. 2, s. 12. 
Słowiańszczyznę, Polacy w odpowiedzi zarzucali takież odstępstwo Rosji, bądź nawet negowali jej charakter słowiański ${ }^{135}$.

Za jedyną właściwie przeszkodę w zawarciu unii Polski z Moskwą Koronowicz uznał różnicę wyznań, ale nie sądził, by była ona zbyt trudna do pokonania. Zachowana jakoby tradycja unii florenckiej "mogła stać się środkiem nieomylnym zjednoczenia, byleby była zręcznie, szczerze, bez łacińskiej pychy, a w miłości chrześcijańskiej duchowieństwu ruskiemu przyniesiona" - twierdził ${ }^{136}$. Ignorowanie rzucającej się w oczy, mocno ugruntowanej niechęci prawosławia do katolicyzmu łączył on z naiwną oceną nieodpartej siły imperatywu wolności, podobną do wiary Lelewela. „Społeczeństwo moskiewskie, od swojego caratu bezecnie pokrzywdzone tak wiele zyskiwało przez dynastyczne z Polską zjednoczenie - pisał - że raz zakosztowawszy słodyczy uczciwego a swobodniejszego rządu, nie chciałoby jej pewnie poświęcić uporowi cerkiewnemu, nie dającemu się usprawiedliwić istotnymi religijnymi powodami"137. Nie lepiej o trzeźwości jego sądu świadczy konstatacja, że "ówczesny rząd moskiewski tak był ciemny, że tego wszystkiego zgoła nie widział", a zatem nie stawiałby przeszkód takiemu otwieraniu drogi dla cywilizacyjnej ekspansji. W ślad za tym szło przekonanie, że „katolicyzm mógł wkroczyć na Moskwę [sic] i w niedługim jak mniemam przeciągu czasu zwyciężyć kościół wschodni na północy"138. Dziejopis nie tylko nie dostrzegał, że z perspektywy rosyjskiej unia brzeska była uważana za odstręczający przykład inwazji łacińskości, ale uznał, że stanowiła wręcz dzieło Opatrzności, które „uściełało drogę" do połączenia obu państw ${ }^{139}$.

Jeśli doszedł do wniosku, że na początku XVII wieku „omal że nie nastąpiło [ich] zjednoczenie", to przesłanką była także teza, że wśród bojarów, którzy jako jedyni w Moskwie „przechowywali święty ogień staro-słowiańskiej zacności", obudził się "duch wolności", przyjmując formę dążeń do elekcji władcy ${ }^{140}$. Wygaśnięcie panującej dynastii, pojawienie się Samozwańca

135. Por. W. Koronowicz [Wróblewski], Słowo..., dz. cyt., t. 2, s. 16; s. 213. O krańcowym przykładzie Franciszka Duchińskiego, który wykluczył Rosjan z kręgu ludów słowiańskich, a nawet aryjskich, pisał Andrzej F. Grabski (Na manowcach myśli historycznej. Historiozofia Franciszka H. Duchińskiego, w: A. F. Grabski, Perspektywy przeszłości, Lublin 1983).

136. W. Koronowicz [Wróblewski], Słowo..., dz. cyt., t. 2, s. 13-14.

137. W. Koronowicz [Wróblewski], Słowo..., dz. cyt., t. 2, s. 15.

138. W. Koronowicz [Wróblewski], Słowo..., dz. cyt., t. 2, s. 13-15.

139. Zob. W. Koronowicz [Wróblewski], Słowo..., dz. cyt., t. 2, s. 213.

140. W. Koronowicz [Wróblewski], Słowo..., dz. cyt., t. 2, s. 218-219. 
i polska interwencja sprzyjały zawarciu unii, a w efekcie gruntownemu przeobrażeniu Rosji - głosił Koronowicz. Nie doszło do tego, gdyż Zygmunt odrzucił zawarty przez Żółkiewskiego układ o elekcji swego syna na tron carów. "Geniusz hetmana" - pisał - pozwolił oddać w polskie ręce "zawojowany i umówiony naród moskiewski", ale wobec "pychy, uporu i mylnych widoków" króla było to daremne ${ }^{141}$. Innych przeszkód dziejopis nie widział, bieg wydarzeń pozwalał mu zaś wnioskować, że różnica religii w istocie znaczyła niewiele. Uważał, że Moskale, „wybierając niemal z uniesieniem cara katolika bardzo się już otarli z myślą przyjęcia unii dwóch obrządków", zatem prawosławie, "dotąd dwa słowiańskie państwa i szczepy wiekuiście od siebie odgradzające", okazało się "do przejednania nie tak trudne"142. Wobec tych odkryć nie dziwi konkluzja, że idea połączenia obu narodów, „,́́więta sprawa pierwotnego słowa Polski, ginęła od złej woli Zygmunta III, a ginęła na zawsze. Moskwa mająca stać się wiekuiście nam bratnią i z nami jak Litwa zjednoczoną, lub przynajmniej wchodzącą w kolej i obyczaje ludów wolnych, a przeto prawdopodobnie niezaborczych, odtąd przeciwnie samowładniej jeszcze rządzona, z uczuciem nieubłaganej nieprzyjaźni, godzić będzie na naszą zgubę, zabierze nam kraj i żywot dziejowy, wydrze ojczyznę"143.

\section{Posłannictwo Polski i wspólnota Słowian w twórczości Matejki}

Niełatwo jest odpowiedzieć na pytanie, w jakim stopniu ta fantastyczna wizja, czy też podobne refleksje (jeśli nawet pozbawione tak śmiałych orzeczeń w odniesieniu do potencjalnych rozstrzygnięć o wymiarze historiozoficznym), mogły oddziałać na przesłanie Kazania Skargi. O ile brak argumentów, że artysta ją podzielał, o tyle wolno sądzić, że mógł go pociągać jej mniej skrajny wariant, skoro elementy podobnej filozofii historii będą pełnić później istotne funkcje w jego twórczości. To właśnie idee powstałe na gruncie mesjanizmu konstytuowały fundament jego wykładni dziejów Polski, a bliska była mu również wiara we wspólnotę ludów słowiańskich. Tę zaś, podobnie jak Mickiewicz, łączył z przekonaniem, że Polska i Rosja stanowią antytezy dziejowe, że polityka rosyjska jest właściwie zaprzeczeniem wartości chrześcijańskich. Twórca Wernyhory pretendował ponadto do pełnienia funkcji następcy wieszczów i znaczna część opinii polskiej tę rangę mu przyznawała.

141. W. Koronowicz [Wróblewski], Słowo..., dz. cyt., t. 2, s. 226.

142. W. Koronowicz [Wróblewski], Słowo..., dz. cyt., t. 2, s. 242.

143. W. Koronowicz [Wróblewski], Słowo..., dz. cyt., t. 2, s. 253. 
W literaturze przedmiotu powtarza się tę frazę niezmiennie jak zaklęcie, ale nie dostrzega się, że oznaczało to twórcze nawiązania do historiozofii Mickiewicza i Krasińskiego. Za szczególnie ważne dokonanie pierwszego z nich artysta uznał wizję dziejów - forsując z uporem swe projekty jego pomnika, powtarzał tam motyw orła, który wzbija się do lotu znad księgi Literatury słowiańskiej. Tezie, że wykładnię dziejów Matejki wiele łączy z historiozofią polskiego mesjanizmu, nie przeczy krytyczny stosunek do wielu istotnych zjawisk ojczystej przeszłości w jego dziełach. Wbrew bowiem banalizującym problem, upowszechnionym mniemaniom, idea opatrznościowej misji Polski, która głosili wielcy romantycy, nie oznacza wcale (szczególnie w przypadku Mickiewicza) bezkrytycznej oceny rezultatów próby jej realizacji ${ }^{144}$.

Idea duchowej wspólnoty Słowian była Matejce, synowi przybysza z Czech, bliska do końca życia, a więc długo po tym, jak patriotyczne elity polskie pojęły, że służy ona imperializmowi rosyjskiemu i przestały się do niej odwoływać. Później jej głoszenie mogło już wręcz narażać na zarzut apostazji, ale dla artysty była to przesłanka braterstwa Polaków i Rusinów, zaś ideę pojednania tych - jak uważał - zwaśnionych szczepów jednego narodu, które gnębił wspólny wróg, Moskwa, wspierał on z wielką wytrwałością. Prawdopodobnie podzielał obiegowe przekonanie polskich romantyków, że Rosjanie ulegając wpływom wareskim, bizantyjskim i mongolskim, utracili słowiańską tożsamość, wydawał się jednak wierzyć, że będzie możliwe obudzenie ich pierwotnego ducha. Nie zważając, że kolejne millenia związane z apostolską misją Cyryla i Metodego władze Rosji wykorzystywały do propagandy prawosławia i swych imperialnych dążeń wśród Słowian na obszarze Austro-Węgier i Turcji, w 1885 roku Matejko przedstawił inicjatywę manifestacji jedności polsko-ruskiej z okazji rocznicy śmierci drugiego z braci. Wspólna pielgrzymka do Welehradu, historycznej stolicy Wielkich Moraw, miała złożyć w miejscowej świątyni obraz-feretron jego autorstwa, ukazujący obu apostołów na tle herbów Polski, Litwy i Rusi. Nie udało mu się jednak uzyskać poparcia elit żadnej ze stron, a przeszkody stawiały też władze w Wiedniu. Dla problematyki niniejszego tekstu ważne jest przede wszystkim to, iż w kontekście tej rocznicy, obchodzonej z pompą w imperium carów,

144. Takie odczytanie przesłania ogółu dzieł Matejki tworzących "główny cykl" dziejów Polski przedstawiłem w: H. M. Słoczyński, Jan Matejko, Kraków 2005. Bardziej szczegółową argumentację zawierają zaś interpretacje niektórych dzieł, jak H. M. Słoczyński, "Hołd Pruski”, dz. cyt., s. 199-238 i H. M. Słoczyński, Racławice i cud..., dz. cyt., s. 223-239. 
artysta wysłał pismo do podrzędnej petersburskiej gazety, gdzie wyraził wiarę w przyszłe pojednanie i współpracę Polski i Rosji. To, że twórca Unii Lubelskiej i Grunwaldu, uważany przez rzesze rodaków za instytucję narodową, wchodził w relacje z takim partnerem, wypowiadał oceny powszechnie odrzucane i wyrażał deklaracje rażąco nieadekwatne do sytuacji, kiedy trwała antypolska, represyjna polityka caratu, wywołało silne oburzenie ${ }^{145}$. Tłumacząc się publicznie, artysta uznał swe wystąpienie za błąd, ale nie wycofał się z myśli o pojednaniu z Rosją. Głosy potępienia uważał za powtórzenie tego, co kiedyś spotkało Mickiewicza, "któren podobno w epoce swego kursu literatury słowiańskiej otrzymał od rodaków stryczek" ${ }^{146}$. Ten wrogi gest wobec wieszcza miał być właśnie reakcją na idee syntezy sprzecznych wartości dziejowych Polski i Rosji oraz koniecznego wkładu tej ostatniej w przyszłe odrodzenie ludzkości, jakie ten wygłaszał z katedry Collége de France ${ }^{147}$.

Wolno sądzić, że idea pojednania obu narodów nie była artyście obca także wtedy, gdy (ponad 20 lat wcześniej) malował Skargę, ale ta konstatacja pozwala tylko na ogólne wnioski, które nie generują jeszcze możliwości bardziej precyzyjnego odczytania przesłania obrazu. Trudno też twierdzić, że Matejko przyjmował filozofię historii Mickiewicza w całej jej rozciągłości (a nie chodzi tylko o stosunek prawowiernego katolika do jej heterodoksyjnego aspektu). Trzeba też pamiętać, że profesor Sorbony był daleki od przedstawiania wolnościowej misji polskiej wobec Rosji w stylu Koronowicza. O ile bowiem poeta-historiozof wyraża idee w abstrakcyjnej postaci i może względnie swobodnie traktować dziejowy konkret, o tyle malarz historyczny nie może abstrahować od konkretu. Oczekiwano od niego zgodnego z realiami przedstawienia strony wizualnej oraz ukazania rzeczywistych osób i ich działań, choć - jak już pisałem - Matejko zastrzegał sobie dużą licencję w łączeniu postaci i zdarzeń.

145. O tym, że nie była to reakcja powodowana przewrażliwieniem, świadczy postawa petersburskiego „Kraju", wtedy bodaj najpoważniejszego polskiego ośrodka propagującego idee ugody z Rosją. Obszerny artykuł wstępny podkreślał, że do takiej inicjatywy „zabrakło obecnie poważnego gruntu", a gazetę „Minuta", do której przesłał ów list artysta, nazwał "brukową" i sugerował jej zdecydowanie wrogie Polsce stanowisko („Kraj" $1885 \mathrm{nr} 24$, s. 1).

146. Rękopis w Domu Jana Matejki MNK (brulion pisma do prasy), DJM IX/2808.

147. O tej kwestii w filozofii historii Mickiewicza: A. Walicki, Filozofia a mesjanizm. Studia z dziejów filozofii i myśli społeczno-religijnej romantyzmu polskiego, Warszawa 1970, s. 278-282; por. też: M. Wodzyńska, Adam Mickiewicz i romantyczna filozofia historii w Collége de France, Warszawa 1976, s. 248-251. 


\section{Idea przeobrażenia Moskwy za sprawą Polski - pytanie o realizm}

Jego wiara w pojednanie z Rosją, którą musiał przecież wiązać z perspektywą przenikania idei wolności do imperium carów, pozwala w każdym razie wnioskować, że dostrzegał też szanse sukcesu skierowanej tam, polskiej misji w epoce pierwszych królów elekcyjnych. Jakkolwiek nie sposób dociec, jak przekładał inspiracje idei romantyków na materię dziejową czasu kazań Skargi i "dymitriady", to należy raczej wykluczać, by mógł skłaniać się ku wizji Koronowicza. W czasie, kiedy malował obraz, był pod dużym wpływem Szujskiego, a ten, choć w niejednej sprawie był wtedy jeszcze dość blisko swych romantycznych korzeni, postrzegał bardziej realistycznie tę problematykę. Przekonanie, że powstała wtedy szansa istotnego oddziałania na przemiany państwa i narodu rosyjskiego, można było jednakże głosić również na gruncie trzeźwego realizmu, jakkolwiek nie sprzyjała temu znana teza o niezmiennie niewolniczej tożsamości rosyjskiej, o ukształtowaniu jej przez nieusuwalny gen, powodujący, że Moskale byli zdolni do egzystencji społecznej jedynie pod rządem despotycznym.

Z tej realistycznej perspektywy łatwo się zgodzić, że gdyby Rzeczpospolita funkcjonowała lepiej, a jej klasa polityczna była bardziej dalekowzroczna i mniej nastawiona na prywatę, to ówczesny zamęt w Moskwie mógł być wykorzystany dużo bardziej efektywnie. Trudniej już zgodzić się z tezą, że któryś z Wazów na tronie carów - jeśli w ogóle mógłby tam zasiąść byłby w stanie dokonać istotnej reformy ustroju i europeizacji społeczeństwa, czy choćby tylko pchnąć je na tę drogę. Wiedza o tym, jaki potencjał oporu ujawniał się w późniejszych czasach, kiedy w Rosji próbowano realizować projekty tak czy inaczej pojętej modernizacji i jakie to przyniosło skutki, winna skłaniać do ostrożności i bodaj do wykluczenia możliwości unii politycznej obu państw, a zwłaszcza wiary w taką jej trwałość i chwalebne skutki, jaką widać w snach romantyków. Ocenę, że było to realne, trudno dziś traktować inaczej, niż jako projekcję w przeszłość myślenia życzeniowego, ale w XIX wieku nie mieli na nią bynajmniej monopolu tacy doktrynerzy, jak Lelewel czy Koronowicz. Przykładem jest Michał Bobrzyński uważany za pozbawionego złudzeń realistę, gdy kilkanaście lat po powstaniu Skargi zwracał się do opinii czytelniczej, której skłonność do ulegania mrzonkom romantyków mocno już osłabiły doświadczenia historyczne ostatniego okresu, jak też propaganda pozytywistycznej trzeźwości. Objęcie tronu w Moskwie przez Wazów uznał on za możliwe i głosił, że projekt ten "otwierał wpływ cywilizacji Zachodu 
na szeroką północ, zbliżał ku sobie dwa pobratymcze narody, a mógł je kiedyś w jedno państwo nierozerwalnie połączyć"148.

Ten przypadek zda się przypominać o oczywistej prawdzie, że współczesnych wyobrażeń o trzeźwości sądów nie należy rzutować na opinie ludzi innej epoki. Przekonanie, że Polska na początku XVI wieku, nie potrafiąc się zdobyć na dalekowzroczną, konsekwentną politykę, czy choćby nie pozwalając, aby kreował ją element anarchiczny, utraciła powstałą za sprawą kryzysu w Rosji wielką szansę, a skutki ówczesnych działań stały się czynnikiem katastrofy państwa w wieku następnym, było w każdym razie w czasach Matejki normą, choć różnie je konkretyzowano. Taką ocenę mógłby wesprzeć fakt względnej popularności kandydatur carów na tron krakowski, ale idea unii personalnej pod ich berłem raczej nie przekonywała ówczesnych historyków. Nieco później Szujski uzna to rozwiązanie za niemożliwe ze względu na różne tradycje polityczne i „wewnętrzne usposobienie" narodu polskiego ${ }^{149}$.

Bardziej realna mogła się wydawać unia pod berłem Wazów - za argument można było uznać zwłaszcza zaawansowaną próbę jej realizacji pod egidą Żółkiewskiego, który skłonił bojarów do obrania królewicza Władysława na tron carski. Warto zauważyć, że urzeczeni perspektywą zawładnięcia Moskwą autorzy wydają się sądzić, że po tej elekcji sprawa była już prosta i wymagała jedynie akceptacji króla Polski. Nie brano pod uwagę, że bojarzy mogli traktować tę opcję jako pociągnięcie taktyczne, z którego można się wycofać w dogodnym czasie, z czego zdawano sobie sprawę na dworze Zygmunta ${ }^{150}$. O realności doprowadzenia do trwałej unii dynastycznej był zaś przekonany hetman polny koronny, który opisał swe działania oraz przedstawił zamysły w niewielkiej książce, znanej i wydawanej w XIX wieku ${ }^{151}$. Zwycięzca spod Kłuszyna chciał prowadzić taką politykę wobec Moskwy, jaką kiedyś podjęto wobec Litwy, a która dopiero po dwóch wiekach doprowadziła do rzeczywistej unii. Podkreślał, że cel tak wielki może być osiągnięty jedynie stopniowo: „pierwej będzie dziecię, potem z czasem człowiek, pierwej mała różdżka, z czasem bywa z niej wielkie drzewo. Wielkie Księstwo Litewskie

148. M. Bobrzyński, Dzieje Polski w zarysie, Warszawa 1987, s. 367.

149. J. Szujski, Maryna Mniszchówna..., dz. cyt. s. 224.

150. Lew Sapieha miał uważać ofiarowanie tronu królewiczowi za fortel, mający powstrzymać potęgę militarną Polski (K. Kognowicki, Żywot Lwa Sapiehy, Sanok 1855, wyd. K. J. Turowski, s. 50-51). Krzysztof Zbaraski także uważał, że wyboru dokonano pod presją sytuacji (J. Maciszewski, Polska a Moskwa..., dz. cyt., s. 217-218).

151. Poczatek $i$ progres wojny moskiewskiej ukazał się tuż przed podjęciem pracy nad Kazaniem Skargi w edycji Pism Żółkiewskiego (wyd. A. Bielowski, Lwów 1861). 
sto sześćdziesiąt lat minęło od unii króla Jagiełła - pisał - niźli do tej, jaka teraz jest, spólności z Koroną przyszło" [sic] ${ }^{152}$.

Należy oczywiście postawić pytanie, czy taka myśl bliska była Skardze. Poświęcona mu literatura bodaj nie odnotowała jej w jego dziełach; nie pojawiła się ona choćby w kazaniu Na moskiewskie zwycięstwo, które - już u kresu swych dni - wygłosił w czasie dziękczynnego nabożeństwa w Wilnie z udziałem króla, wracającego po zdobyciu Smoleńska. Nie oznacza to jednak, że myśl taka była mu obca, skoro to właśnie strategia Żółkiewskiego mogła stworzyć najlepszą podstawę - choć dopiero w dłuższej perspektywie - realizacji planów jego zakonu wobec prawosławia. Kaznodzieja nie mógł jej wtedy wyrazić, nie szkodząc królowi w oczach przeważającej części opinii, która wojnę z Moskwą wiązała z intrygą jezuitów i celami Polsce obcymi oraz z dynastycznymi planami tronu, które mogły zagrozić dogmatyzowanej wolności szlacheckiej ${ }^{153}$. Należy więc zauważyć, że o ile obecność na obrazie małoletniego królewicza Władysława wiąże się z dążeniami jego ojca do zapewnienia mu tronu polskiego ${ }^{154}$, o tyle w nie mniejszym stopniu wynika ona z jego roli w polityce wobec Rosji, a obie te sprawy blisko się łączyły. We wspomnianym kazaniu, swej ostatniej mowie triumfalnej, Skarga ostrzegał zaś przed niewykorzystaniem wielkiego zwycięstwa nad Moskwą i zmarnowaniem szansy, którą zesłał Bóg. Uznając, że niespotykany upadek nieprzyjaciela, który od dawna zagrażał Polsce, stworzył nadzieje "stałego i zupełnego" pokoju, wzywał dalej: „pobudzajmy się do wdzięczności i posiłków takiego zwycięstwa i darów Bożych, abyśmy nadaremnie łaski Bożej nie brali, ale ją na dobre swoje obrócić umieli, żeby nam nie rzeczono: Vincerescis uti victoria nescis" ${ }^{\prime 155}$.

152. S. Żółkiewski, Początek i progres wojny moskiewskiej, Kraków 1998, s. 106. Zapis o unii, generalnie zgodny z propozycjami z 1600 roku, znalazł się w umowie, jaką zawarł Władysław jako wybrany car Rosji ze swym ojcem jako królem Polski, gdy w 1617 roku ruszał na wojnę w imię praw do tronu w Moskwie. Zobowiązał się tam, że po objęciu władzy nakłoni poddanych, aby między obu ludami „braterska i szczera miłość zakwitła" oraz że będzie działał w ścisłym porozumieniu z Rzeczpospolita, "aby tak przyjaciele, jako i nieprzyjaciele poznali, iż oba te ludy dla wspólnego dobra jednym tchnący duchem nierozerwalny zawarli związek" (K. Sienkiewicz, Skarbiec historii polskiej, dz. cyt., t. 1, s. 345).

153. Szlachta obawiała się, że objęcie władzy w Moskwie przez Władysława zapewni mu tron w Warszawie, co będzie oznaczać koniec wolnej elekcji (J. Maciszewski, Polska a Moskwa..., dz. cyt., s. 207).

154. Por. J. Krawczyk, Matejko i historia, dz. cyt., s. 105-106.

155. P. Skarga, Na moskiewskie zwycięstwo kazanie i dzięki Panu Bogu, w: P. Skarga, Pisma wszystkie, t. 3, Warszawa 1925, s. 117, s. 127. 


\section{Szujski a kwestia posłannictwa Polski wobec Rosji}

Bez wątpienia ważne, a być może decydujące znaczenie dla ukształtowania poglądów artysty w okresie pracy nad Kazaniem Skargi, miały sądy Szujskiego zawarte w Dziejach Polski. Już przytoczone dotychczas wskazują, że uważał on prywatną interwencję w Moskwie za wyraz narastającej anarchii i przeszkodę w realizacji wielkiego politycznego zadania na Wschodzie. Twierdził, że był to „objaw decentralizacji państwa", a postępowanie Mniszcha, Rożyńskiego i Sapiehy wypływało z tego źródła, co bunt Zebrzydowskiego. "Ten sam duch indywidualizmu, który wewnątrz tworzył rokosze - pisał objawiał się na zewnątrz w wojnach prowadzonych przez prywatne osoby"156. Ale utraconą wtedy szansę łączył też, tak jak powszechnie czyniono przed nim, z nieudolną polityką króla. Uważał za słuszną strategię Żółkiewskiego i powtarzał za dziełem bp. Pawła Piaseckiego, że do tego, by zniweczyć ówczesne wielkie perspektywy, "nie wystarczał jeden błąd", trzeba ich było popełnić wiele ${ }^{157}$. Zawarte tu przekonanie, że względnie trwały sukces był wtedy łatwy do osiągniecia, brzmi naiwnie, co zresztą w jego książce zdarza się też w ujęciu innych kwestii. Pisanie Dziejów Polski było dopiero szkołą młodego badacza, autodydaktycznym seminarium historycznym, jak pisał jego następca na katedrze uniwersyteckiej, Stanisław Smolka ${ }^{158}$.

Bez wątpienia Szujski dostrzegał możliwość definitywnego rozstrzygnięcia rywalizacji Polski i Rosji, likwidującego trwale zagrożenie z północnego wschodu, choć takiej myśli w Dziejach Polski nie wyraził wprost. Ale też ówczesnej porażki Rzeczpospolitej nie sprowadzał jedynie do owych jak ujął Niemcewicz - "opuszczonych korzyści"; bilans interwencji nie był zerowy, lecz ujemny, a saldo obciążały nie tylko zmarnowane siły i środki. Zasadnicze znaczenie miał dlań fakt, że między skazanymi na sąsiedztwo narodami powstała przepaść. Podnoszenie takich skutków wojny było zgodne

z relacją Żółkiewskiego, który pisał, że żołnierze polscy w służbie łże-Dymitra "rozpustnie żyli, zabijając, mordując, gwałcąc, nie tylko czemu inkszemu, ale i cerkwiom nie przepuszczali"159. Szujski nieraz podkreślał fakt dokonanych okrucieństw, grabieży i profanacji; wskazywał, że "nadużycia" wojska

156. J. Szujski, Dzieje Polski, t. 3, dz. cyt., s. 222.

157. J. Szujski, Dzieje Polski, t. 3, dz. cyt., s. 230, 232-233.

158. S. Smolka, Józef Szujski. Jego stanowisko w literaturze i społeczeństwie, Kraków 1883, s. 33 .

159. S. Żółkiewski, Początek i progres..., dz. cyt., s. 58; hetman podał też, że profanacji dopuszczali się żołnierze Sapiehy (Początek i progres..., dz. cyt., s. 81). 
drugiego Samozwańca, które ściągało „ogromne kontrybucje i dopuszczało się wszelkiego rodzaju gwałtów, były okropne" i że Polacy "rabowali i nękali mieszkańców, przywodząc ich tym samym do rozpaczy i buntu"160. Trudno tu powstrzymać się od refleksji, że fakty te (pomijając nawet wszechobecną pogardę do Rosjan), stanowią najlepszą odpowiedź na pytanie o realność ówczesnych projektów unii ${ }^{161}$. Zarazem pozwalają one na jednoznaczne wnioski w kwestii nieuchronnego wpływu tej interwencji na ukształtowanie się obrazu Polski w oczach sąsiedniego narodu.

Oceny, że wojna otwarła przepaść we wzajemnych stosunkach, Szujski nie wyraził literalnie, lecz w formie metafory ubranej w antyczną szatę. To, że "wzgardzony naród moskiewski zdobył się na jedną piękną chwilę w swojej historii, na dzielną walkę przeciw swawolnym, okrutnym i niemoralnym najeźdźcom, jakimi byli Polacy, popierający samozwańców, łaknący skarbów moskiewskich, hańbiący imię swoje okrucieństwem i chciwością bez granic", pozwoliło mu dostrzec rękę "Nemezys historycznej"162. Mało więc twierdzić, że zbrodnie popełnione w czasie interwencji wykluczyły możliwość wszelkich planów unii na przyszłość, gdy stanowiły one wyzwanie Moskwy "do ustawnego boju"163. Szujski dostrzegał ponadto negatywny wpływ tej wojny na sprawy wewnętrzne Rzeczypospolitej, tzn. istotne wzmożenie przesłanek destrukcji ładu politycznego i moralnego. Instynkty rozbudzone już

160. J. Szujski, Dzieje Polski, dz. cyt., t. 3, s. 224-225. Historyk wspomninał też o "rozdrapaniu bogatego skarbca carskiego" i pisał, że „uwiezienie Szujskich do obozu królewskiego, swawola pozostałych załóg polskich, oburzały naród", zaś oddziały Sapiehy nazywał „zbestwionymi" (J. Szujski, Dzieje Polski, dz. cyt., t. 3, s. 229230). Ze skarbca zrabowano wtedy m.in. korony i inne carskie insygnia koronacyjne (J. U. Niemcewicz, Dzieje panowania..., dz. cyt., t. 3, s. 20-21).

161. XX-wieczny uczony pisał, że „podkreślana we wszystkich źródłach pycha, domaganie się specjalnych praw i przywilejów z racji przynależności narodowej, pogarda okazywana rodowitym Rosjanom dowodzi, że na tym gruncie budowanie jakichkolwiek dalekosiężnych planów zbliżenia między obu państwami (jeśli takie plany były) było zupełnie nierealne" (J. Maciszewski, Polska a Moskwa..., dz. cyt., s. 82).

162. J. Szujski, Dzieje Polski, dz. cyt., t. 3, s. 233.

163. J. Szujski, Dzieje Polski, dz. cyt., t. 3, s. 271. Nieco później pisał on o bilansie interwencji: „naród, który miał sąsiedniemu ludowi dać pana, pogodzić się pod berłem jednej rodziny królewskiej, polecił się temuż sąsiadowi jak najgorzej, bo swawolnemi kupami, które niepłatne rzucały się na bezprawia i oburzały Moskali. I to jak gdyby na karę tych wszystkich przewinień, wydobywa się ze sponiewieranego, uciśnionego niewolą, pogardzonego ludu moskiewskiego, duch niepodległości, duch oporu w imię wiary i obyczaju, i duch ten odnosi zwycięstwo nad swawolnem męstwem, któremu myśl polityczna towarzyszyć przestała" (Maryna Mniszchówna..., dz. cyt., s. 269). 
podczas rokoszu wchodziły w krew żołnierzy w trakcie działań pacyfikacyjnych w Rosji, gdy ci, pozbywszy się wszelkich hamulców, dokonywali strasznych ekscesów. Tę demoralizację trudno już było opanować, gdy do kraju powróciły rozwydrzone kupy weteranów; historyk uważał, że "jeśli rokosz Zebrzydowskiego wzgardę władzy i prawa powszechną uczynił, to wielka migracja rycerstwa do Moskwy, jego rozbestwienie, powiększyło jeszcze ten okropny symptomat"164.

Generalnie Szujski sądził, że Polska powinna wykorzystać kryzys w Moskwie i wystąpić zbrojnie ${ }^{165}$, ale też, że należało działać tak, by wojna była prowadzona z carem, który miał wtedy ograniczone poparcie społeczne, a nie z całym narodem. To, że sprawa potoczyła się drogą tak fatalną w skutkach, wiązał zaś z ujawnieniem się siły żywiołu anarchicznego, który napędzał działania Mniszcha i Sapiehy oraz odpowiadał za brak karności i ekscesy żołnierza. Jednak pole jego działania stworzyła polityka króla, który zamiast we właściwym momencie wystąpić otwarcie i energicznie, skrycie popierał prywatną interwencję w początkach całej sprawy. Wpływały na to w dużym stopniu dążenia jezuitów i papieża; historyk sądził, że król „wdał się w intrygę" Mniszcha z Samozwańcem „dla dalekich jakichś i niepewnych celów propagandy katolickiej"166. Pisał, że już od czasów Batorego „lekkomyślne mrzonki połączenia Moskwy zwyciężały" w planach Stolicy Apostolskiej „nad interesem prawdziwym Polski i katolicyzmu"167. Kiedy konstatował, że króla opanowali "zupełnie" jezuici, to chodziło mu także o działania wobec państwa carów; zakon - podkreślał - „gotów był nawet poświęcić dobro Rzeczpospolitej dla błahej nadziei nawrócenia Rosji"168.

164. J. Szujski, Dzieje Polski, dz. cyt., t. 3, s. 233.

165. Przekonany, że w planach Batorego było „wywrócenie Moskwy i połączenie jej z Polską", uważał on za pewnik, że droga ta „była jedyną, jaką Polskę z niebezpieczeństw uratować było można" (J. Szujski, Dzieje Polski, dz. cyt., t. 3, s. 103-105). Oceniając tę wypowiedź w szerszym kontekście poglądów historyka, wydaje się, że nie oznacza ona przekonania o realności trwalszej unii - raczej chodziło o przejściową dominację polską, która wystarczyłaby, by obalić system tyranii i skierować Rosję na drogę zmian. Widać w każdym razie jego większą ostrożność, generującą obraz zasadniczo różny od mirażu "nierozerwalnego" połączenia w „jedno państwo" Bobrzyńskiego.

166. J. Szujski, Dzieje Polski, dz. cyt., t. 3, s. 186.

167. J. Szujski, Dzieje Polski, dz. cyt., t. 3, s. 83. W nieco późniejszej rozprawie napisze on, że Zygmunt III przyjął od „kurii rzymskiej fałszywe zapatrywanie się na Moskwę [...] jako przyszłą neofitkę katolicką" (Maryna Mniszchówna..., dz. cyt., s. 226).

168. J. Szujski, Dzieje Polski, dz. cyt., t. 3, s. 161, 280. 
Jeśli Szujski krytycznie odnosił się do tej polityki instytucji kościelnych, to nie ze względu na jej cele, nie dlatego, by uważał dążenie do objęcia Moskwy unią wyznań za niewłaściwe - chodziło o to, że wiara w dobrowolną zgodę cara na to rozwiązanie była skrajnie naiwna i utrudniała realną politykę. Nie mógł się bowiem łudzić i uważać, że neutralizacja rosyjskich dążeń imperialnych mogła nastąpić bez zmiany charakteru religii, która była zintegrowana z systemem władzy, legitymizowała ją i uzasadniała jej ekspansywne dążenia, wyposażając w ideologię kontynuacji cesarstwa wschodniego. Świadomy sojuszu „azjatyckiej” tyranii władców moskiewskich z Cerkwią prawosławną i jej bizantyjską tradycją służenia cesarzowi, historyk podkreślał, że Moskwa „w imię schizmy i caratu [...] torowała sobie drogę do serca Europy" oraz że "misją" Polski było „odpieranie moskiewskiej szyzmatyckiej nawały"169.

Przeciwstawianie Polski i Rosji jako dwóch diametralnie różnych cywilizacji, ufundowanych na zasadniczej różnicy religii, stanowiło w myśli polskiej po powstaniu listopadowym swoisty kanon. Stąd wynikała teza o z gruntu pokojowym, odrzucającym podbój postępowaniu Polski i brutalnej zaborczości Moskwy. Tezę o integralnym związku jej fundamentów religijnych z dążeniami imperialnymi wyrażał dobitnie Zygmunt Krasiński, konstatując "zwierzchnictwo władzy świeckiej nad duchową, czyli uznanie wyższości i panowania ciała nad duszą za zasadę schizmy moskiewskiej. Zasada schizmy ta sama, co kalifatu - pisał - stanowi właśnie usprawiedliwienie ducha moskiewskiego przed sobą samym i jest mu największą pomocą moralną do wytrwania w chuci podboju świata, dozwala wprost sumieniu jego w niej się rozkoszować"170. Szujski kreślący obraz agresji moskiewskiej "w imię schizmy" sytuował się blisko tych idei. Autor Psalmów przyszłości był zresztą poniekąd patronem jego Dziejów Polski - słynne słowa "Wszystko nam dałeś, co dać mogłeś, Panie", uznał on przecież za motto dzieła. Warto podkreślić, iż ten motyw przewodni łączy się z przekonaniem, że przodkom zabrakło kiedyś "dobrej woli", by owe dary i szanse w pełni wykorzystać.

169. J. Szujski, Dzieje Polski, dz. cyt., t. 2, s. 378, t. 3, s. 533, t. 2, s. 415; historyk pisał także, że "szyzmatycki carat moskiewski" wkraczał na drogę ekspansji ku Europie przybrany w "zblakłe purpury" Bizancjum (Dzieje Polski, dz. cyt., t. 2, s. 11).

170. Z. Krasiński, Uwagi nad dziełem o Rosji, Europie i Polsce, w: Z. Krasiński, Pisma filozoficzne i polityczne, wyd. P. Hertz, Warszawa 1999, s. 276. 


\section{Nieobecność zdobywcy Moskwy w obrazie}

Tezę, że wielka szansa, jaką stworzył kryzys w Rosji, została zmarnowana przez anarchiczny charakter prywatnej interwencji i towarzyszące jej ekscesy, które wykopały przepaść między obu narodami, Szujski łączył z przekonaniem, że skutki byłyby inne, gdyby realizowano strategię Żółkiewskiego. Karty jego Dziejów Polski mieszczą najwyższe pochwały talentów hetmana i jego patriotyzmu - jest on tam wzorem „szczerych miłośników Rzeczpospolitej oraz jednym z najczystszych ludzi w naszej historii" ${ }^{171}$; zarazem historyk zaznaczył, że sprzeciwiał się on popieraniu fałszywego Dymitra ${ }^{172}$. Trzeba zatem odnotować brak postaci zwycięzcy spod Kłuszyna i zdobywcy Moskwy w Skardze, gdzie malarz przywołał przecież tę dającą mu wiekopomną sławę wojnę, a ponadto obraz miał stanowić wizję epoki, w której należał on do głównych aktorów. Wydaje się, że nie jest to przypadkowe, a ta nieobecność jest przemyślana i znacząca. Uznanie tego, co pominął artysta, za przesłankę wnioskowania o jego intencjach, nie jest chyba tak absurdalne, jak z pozoru może się wydawać. W tym przypadku brak ten wydaje się dobrze wpisywać w cały kompleks znaczeń, wydobytych w trakcie odczytywania dzieła. Dodatkową zachętą do uwzględnienia tego spostrzeżenia jest casus firmowany przez świetne nazwisko.

W 1942 roku Karol Wojtyła napisał dramat Jeremiasz, którego tytułowym bohaterem jest Piotr Skarga. Przeżywa on najpierw wizję, w której biblijny prorok piętnuje przewiny króla i elit Izraela oraz zapowiada przyszłe klęski narodu. Treść jego napomnień uświadamia Ojcu Piotrowi analogię z sytuacją Rzeczpospolitej, toteż w nauce kierowanej do sterników jej nawy przyjmuje podobną rolę. Wskazani w didaskaliach słuchacze są dokładnie tymi postaciami, które ukazał w swej kompozycji Matejko. Ale oprócz nich ostrzeżeń i proroctwa polskiego Jeremiasza słucha niewidoczny, ukryty gdzieś w cieniu w nawie katedry na Wawelu hetman Stanisław ze Żółkwi ${ }^{173}$. Autor dał zatem do zrozumienia, że obraz Matejki stanowi punkt odniesienia sceny i że dostrzegł w nim brak postaci, którą "dokooptował" w swym dramacie. Hetman staje się dalej interlokutorem Ojca Piotra, drugim głównym bohaterem utworu, a ich troski i diagnoza są w pełni zbieżne. Znamienne,

171. J. Szujski, Dzieje Polski, dz. cyt., t. 3, s. 215, 248.

172. Zob. J. Szujski, Dzieje Polski, dz. cyt., t. 3, s. 194.

173. Uwzględniając oczywiście przedstawione wyżej wątpliwości w odniesieniu do paru mniej ważnych postaci; jest tu więc Zbaraski i Halszka z Ostroga (K. Wojtyła, Jeremiasz, w: K. Wojtyła, Poezje i dramaty, Kraków 1998, s. 386). 
że przyszły papież i święty nie obsadził w tej roli Zamoyskiego, któremu wedle zgodnej tradycji interpretacji powierzył ją malarz ${ }^{174}$. Należy zaznaczyć, że główny problem Jeremiasza stanowi dojmujący deficyt prawdy w życiu publicznym Polski, a sprawa roli Żółkiewskiego w wojnie z Moskwą pojawia się tylko w krótkiej, ale znamiennej frazie, którą wypowiada jego zjawa (po śmierci interlokutorzy spotkali się bowiem ponownie): „kiedym do Moskwy polskie wewiódł szyki, kiedym był bliski ziścić wielką sprawę..."175 [podkr. H. M. S.].

\section{Przesłanie: cały naród szlachecki winny utraty dziejowej szansy}

Konkluzja, że kwintesencja przesłania Kazania Skargi wyraża się w sugestii, iż odrzucenie planów hetmana było przyczyną zaprzepaszczenia ówczesnych możliwości, a w efekcie późniejszego upadku Polski, zyskuje zatem dodatkową przesłankę. Matejko zapewne uważał tak jak Szujski, że nie wolno było dopuścić, by wojna z Moskwą przyniosła tyle nadużyć, które pozostawiły Rosjan z bezmiarem upokorzenia i nienawiści do Polaków, stając się przez to czynnikiem umocnienia ich niechęci do religii i cywilizacji Zachodu. Pewnie podzielał również myśl przyjaciela-historyka, że ten bieg rzeczy wynikał z anarchicznego systemu Rzeczpospolitej, aczkolwiek działania magnatów poza jej granicami i ich prywatne wojny nie były kojarzone tak powszechnie z rozkładem państwa, tak jak wewnętrzny chaos i bezprawie. A zatem Mniszech i Sapieha, podobnie jak Zebrzydowski, Radziwiłł i Stadnicki, wyobrażają w obrazie anarchię w dawnej Polsce - to dwa jej skrzydła, które poniosły naród w otchłań przyszłej niewoli, ku spełnieniu proroctw Skargi.

Krytycznie oceniając politykę Zygmunta III z powodu utraty szansy, jaką stworzył kryzys w Moskwie, Szujski obwiniał w niemniejszym stopniu naród, który „zachował się obojętnie, nieudolnie, a nawet niechętnie wobec wielkiej sprawy, toczącej się na Wschodzie". Historyk wskazywał, że „zdemoralizowany rokoszem kraj poczytywał ją za prywatną króla wyprawę" i ubolewał, że „wspaniałe dzieło patriotycznego hetmana trwało tylko krótką chwilę, pokolenie współczesne, prowadzące kupami swawolnemi samozwańców na tron carski, nie umiało utrzymać na nim królewicza polskiego, nie umiało

174. Warto zauważyć, że Szujski, który niejednoznacznie oceniał Zamoyskiego, widział w przywódcach rokoszu odbicie jego gorszej strony, w Żółkiewskim zaś tę "lepszą, zacniejszą" (Dzieje Polski, dz. cyt., t. 3, s. 273).

175. K. Wojtyła, Jeremiasz, dz. cyt., s. 424. 
rozstrzygnąć długowiecznego sporu z północnym sąsiadem na korzyść obu stron"176. Należy podkreślić, że uwaga o "korzyści obu stron" może tu oznaczać tylko przekonanie o możliwości wewnętrznego przeobrażenia Rosji pod wpływem Polski oraz ukształtowaniu się relacji bez wzajemnej wrogości, a nie myśl o jej podboju i utrzymywaniu w zależności siłą.

Uważam, że te generalizujące uwagi historyka odpowiadają treści obrazu Matejki, że artysta odniósł się także do kwestii winy ogółu szlachty za utratę dziejowej szansy. Na pierwszym planie obrazu, pomiędzy przywódcami rokoszu a protagonistami "dymitriad" (miejsce raczej nieprzypadkowe) widać drzemiącą postać, o której Gorzkowski napisał: "tłusty, barczysty, nieco bezmyślny i w sennem usposobieniu szlachcic" i dodał, że jest to "typ ówczesnej szlachty, której niemoc i poddanie się wpływom możniejszych, były jej cechą zwyczajną"177. Widać oto niezdolny do zrozumienia spraw państwa, zapatrzony w swe przywileje, pogrążający się w apatii naród szlachecki. W przyjętej entuzjastycznie kompozycji Matejko zawarł więc mocno krytyczną ocenę, oskarżając o spowodowanie katastrofy państwa całą panującą warstwę, cały szlachecki naród dawnej Polski, a nie tylko wąski krąg magnatów, jak to czyniono na ogół dawniej, idąc za Lelewelem. O ile oczywistością był ogólnie krytyczny wydźwięk dzieła (tak jak oczywista była wymowa nauk Skargi) o tyle fakt, iż nie dociekano szczegółowo związku wyobrażonych postaci z wiedzą o epoce, każe wątpić, czy zrozumiano wtedy, jak szeroko adresował swe oskarżenia artysta. W późniejszym o trzy lata Upadku Polski wyraził on taką krytykę bardziej dosadnie, a przy tym pojawiły się przesłanki, że idea tego dzieła ma związek z publicystyką Szujskiego spod znaku liberum conspiro ${ }^{178}$. W tej sytuacji ocena, że historia Polski "ma już swego malarza", która była reakcją na Kazanie Skargi, stanęła pod znakiem zapytania i dopiero po kolejnym obrazie - Unii Lubelskiej - stała się znowu powszechnym przekonaniem.

176. J. Szujski, Maryna Mniszchówna..., dz. cyt., s. 268-269.

177. M. Gorzkowski, Wskazówki do dawniejszego obrazu Jana Matejki "Kazanie Skargi", Kraków 1884, s. 11.

178. Por. H. M. Słoczyński, Krytyczna interpretacja dziejów narodowych Józefa Szujskiego a "Upadek Polski" Jana Matejki, w: Krakowska szkoła historyczna a Polskie Towarzystwo Historyczne. Studia historiograficzne, red. P. Biliński i P. Plichta, Warszawa-Kraków 2017, s. 217-240. 


\section{Bibliografia}

Dzieduszycki M., Piotr Skarga i jego wiek, t. 1-2, Kraków 1850.

Gorzkowski M., Wskazówki do dawniejszego obrazu Jana Matejki

"Kazanie Skargi", Kraków 1884.

Koronowicz [Wróblewski] W., Słowo dziejów polskich, t. 1-2, Lipsk 1858,

t. 3, Lipsk 1860.

Krawczyk J., Matejko i historia, Warszawa 1990.

Mickiewicz A., Literatura słowiańska, w: A. Mickiewicz, Dzieła, t. 8,

Warszawa 1997.

Naruszewicz A., Żywot Jana Karola Chodkiewicza, t. 1-2, Kraków 1858.

Niemcewicz J. U., Dzieje panowania Zygmunta III, t. 1-3, Kraków 1860.

Niemcewicz J. U., Śpiewy historyczne, Kraków 1835.

Ożóg K. S., Orzeł biały na tle mroków nocy. Ikonografia Piotra Skargi,

Kraków 2012.

Poprzęcka M., Jak Jan Matejko malował "Kazanie Skargi”, w: Janowi

Matejce w stulecie śmierci. Pamiętnik wystawy w Muzeum

Narodowym w Krakowie, Kraków 1994.

Poprzęcka M., Co mówi Skarga, w: M. Poprzęcka, Kochankowie z masakra $w$ tle $i$ inne eseje o malarstwie historycznym, Warszawa 2004.

Porębski M., Jana Matejki "Kazanie Skargi", Kraków 1953.

Schmitt H., Rokosz Zebrzydowskiego, Lwów 1858.

Skarga P., Kazania sejmowe, także Wzywanie do pokuty obywatelów Korony

Polskiej, wydanie K. J. Turowskiego, Kraków 1857.

Słoczyński H. M., Jan Matejko, Kraków 2005.

Szujski J., Dzieje Polski, t. 3, w: J. Szujski, Dzieła, seria II, t. 3, Kraków 1894.

Szujski J., Maryna Mniszchówna i obaj Samozwańce, w: J. Szujski, Dzieła, seria II, t. 5, Kraków 1885.

Tazbir J., "Kazanie Skargi" Jana Matejki, w: Sztuka i historia. Materiały Sesji Stowarzyszenia Historyków Sztuki, Kraków, listopad 1988, red.

M. Bielska-Łach, Warszawa 1992.

Wielewicki J., Dziennik spraw domu zakonnego O.O. jezuitów u Św. Barbary w Krakowie od r. 1620 do r. 1629 (włącznie), Kraków 1886 (Scriptores Rerum Polonicarum, 10). 
Witkiewicz S., Matejko, Lwów 1912.

Wojtyła K., Jeremiasz, w: K. Wojtyła, Poezje i dramaty, Kraków 1998.

Zgórniak M., Matejko w Paryżu, Kraków 1998.

Żółkiewski S., Początek i progres wojny moskiewskiej, Kraków 1998.

114 Folia Historica Cracoviensia 24 (2018) z. 1 


\section{Abstrakt}

Henryk M. Słoczyński

Kazanie Skargi Jana Matejki w kontekście ówczesnej wiedzy o epoce i poglądów na dzieje Polski

Autorzy zajmujący się twórczością największego malarza dziejów Polski, Jana Matejki, długo nie prowadzili systematycznych badań licznych odniesień do konkretnej materii historycznej w jego dziełach, ignorując ten ich aspekt, któremu artysta przypisywał szczególną wagę. W przypadku Kazania Skargi, jednego z najwybitniejszych jego dzieł, zmianę w tym zakresie przyniosła książka Jarosława Krawczyka Matejko i historia, ale autor skupił się tylko na jednym motywie: walce szlachty z tronem Zygmunta III. Publikowana tu rozprawa pokazuje, że niemniej ważne w treści obrazu są problemy unii religijnej oraz podporządkowania Polsce Rosji na początku XVI wieku. To poszerzenie interpretacji opiera się na próbie sprecyzowania, jaka wiedza o tych sprawach była dostępna artyście. Niewątpliwie szczególne znaczenie miała dlań inspiracja przyjaciela, Józefa Szujskiego, który wtedy opublikował traktujący o tej epoce tom Dziejów Polski. Ujęcie problemów tego okresu w tej książce oraz w obrazie wykazuje daleko idącą zbieżność, zaś istotą przesłania Kazania Skargi jest (znany także z innych dzieł Matejki) motyw utraconej przez Polaków wielkiej szansy dziejowej. Chodziło o szansę opanowania i ucywilizowania Moskwy, a konsekwencją jej utraty było powstanie imperium - przyszłego zaborcy Polski.

Słowa kluczowe: Jan Matejko, Józef Szujski, interpretacja obrazu historycznego, historiografia polska XIX wieku 


\section{Abstract}

Henryk M. Słoczyński

Jan Matejko's Skarga's Sermon in the Context

of the then Knowledge of the Epoch

and Views on Poland's History

Keywords: Jan Matejko, Józef Szujski, interpretation of a historical painting, $19^{\text {th }}$ century Polish historiography
Authors studying the works of the greatest painter of the history of Poland Jan Matejko have long failed to do systematic research on numerous references to specific historical matters in his work, ignoring the aspect to which the artist attached such great importance. In the case of Skarga's Sermon, one of his most iconic works, the situation has changed due to Jarosław Krawczyk's book Matejko i historia, even though the author focused on one theme only: the conflict between the nobility and king Sigismund III. The study published here shows that equally important were the problems of Poland's religious union and its submission to Russia in the early $16^{\text {th }}$ century. Such broader interpretation is based on the assessment of the knowledge of such matters which was available to the artist. Undoubtedly, the fact that Matejko was inspired by his friend Józef Szujski, who back then had published a volume of his work Dzieje Polski concerning that part of the history of Poland, is particularly significant. The issues of the period discussed in the book and shown in the painting reveal far-reaching consistency, and the essence of Skarga's Sermon is the subject of a great historical opportunity which Poles had lost(also know from Matejko's other works). Poland had wasted its chance to take control of Moscow and to civilize it, which led to the rise of an empire - Poland's future oppressor in the partition period. 